\title{
Pembuatan Aplikasi Terintegrasi, Pendataan Barang di Gudang Berbasis Android
}

\author{
Dodi Triwibowo, Rinta Kridalukmana, Kurniawan Teguh Martono \\ Program Studi Sistem Komputer Fakultas Teknik Universitas Diponegoro \\ Jalan Prof. Sudharto, Tembalang, Semarang, Indonesia \\ silveriuz16@gmail.com
}

\begin{abstract}
Abstrak - Dalam Industri yang semakin pesat perkembangannya, proses keluar masuknya barang perlu dicatat, ini diperlukan untuk mempermudah suatu perusahaan dalam mengontrol stok barang baik keluar ataupun masuk. Data fisik merupakan sesuatu yang mudah hilang, pengandaan data juga akan memberikan suatu redundant bagi seorang pekerja, dimana dimungkinkan adanya Human Error, salah satu akibatnya adalah dapat menyebabkan suatu perbedaan data, dimana dari beberapa data yang ada dapat berbeda nilai, ketika terdapat masalah seperti ini dapat merugikan perusahaan ataupun client dari perusahaan tersebut. Aplikasi ini juga dapat membantu perusahaan dalam melakukan checking barang secara cepat, sehingga perusahaan dapat menangani dengan cepat adanya suatu perubahan maupun kesalahan yang terjadi. Pembuatan aplikasi terintegrasi ini menggunakan bahasa pemrograman Java, PHP, dan database MYSQL serta menggunakan JQuery Mobile.
\end{abstract}

Kata Kunci : Android, Sistem, PHP, MySQL, WebView.

\section{PENDAHULUAN}

$\mathrm{S}$ eiring dengan perkembangan jaman, banyak hal yang dapat diselesaikan dengan Teknologi. Pada masa sekarang banyak dikembangkan Sistem Informasi yang bertujuan untuk memberikan kemudahan kepada penggunanya, Sistem Informasi dibangun sedemikian rupa sehingga dapat meningkatkan kinerja bagi suatu Perusahaan, Industri, Instansi, Organisasi, maupun Usaha Mandiri. Dalam perkembangannya integrasi antar sistem yang dimiliki sangat diperlukan. Dengan adanya integrasi ini dimungkinkan kita dapat melakukan suatu kerja dengan cepat, tepat dan lebih efektif serta efisien, dengan adanya pengintegrasian sistem secara menyeluruh dapat memberikan kemudahan kepada pengguna dimana salah satu keuntungannya adalah data cukup disimpan sekali, data dapat diakses darimana saja dan nilainya akan selalu sama, walaupun nantinya sistem yang terintegrasi ini akan memunculkan masalah-masalah baru seperti jika terjadi kesalahan data maka salah semua, kemudian jika data hilang maka akan hilang pada semua sistem, namun masalah tersebut dapat kita tangani nantinya.

Aplikasi terintegrasi ini dibuat berdasarkan Sistem Informasi perusahaan yang sudah ada, mengacu dari hal tersebut aplikasi ini dibuat agar di gudang dapat melakukan crosscheck terhadap pengiriman yang akan dilakukan sehingga pihak checker digudang dapat melakukan pemeriksaan secara cepat dengan mengacu pada basisdata yang ada pada perusahaan, sehingga ini akan membuat pekerja melakukan pekerjaannya dengan baik dan cepat..

Dalam pembuatan tugas akhir ini pembahasan masalah memiliki batasan pada permasalahan berikut :

a. Pembuatan Aplikasi Terintegrasi, Pendataan Barang di Gudang berbasis Android menggunakan bahasa pemrograman Java, PHP, HTML, CSS, Javascript, Framework JQuery, JQuery Mobile dan basisdata MySQL.

b. Hasil aplikasi akan disimulasikan di Webhosting dengan menggunakan beberapa Gadget Android.

c. Aplikasi yang dibuat hanya untuk sisi pengguna yaitu Operator yang ada digudang. d. Aplikasi dijalankan pada perangkat Android dengan sistem operasi minimal versi 4.0 Android IceCreamSandwich hingga versi terbaru 5.0.1 Android Lolipop.

\section{LANDASAN TEORI}

\section{A. Sistem Informasi}

Sistem adalah sekumpulan objek-objek yang saling berelasi dan berinteraksi serta hubungan antar objek bisa dilihat sebagai satu kesatuan yang dirancang untuk mencapai satu tujuan. Informasi adalah data yang telah diolah menjadi sebuah bentuk yang berarti bagi penerimanya dan bermanfaat dalam pengambilan keputusan saat ini atau mendatang.

Sistem Informasi dapat diartikan dengan suatu sistem di dalam organisasi yang mempertemukan kebutuhan pengolahan transaksi harian, mendukung operasi, bersifat manajerial dan kegiatan strategi dari suatu organisasi, dan menyediakan pihak luar tertentu dengan laporan-laporan yang diperlukan atau kumpulan elemen yang saling berhubungan satu sama lain yang membentuk satu kesatuan untuk integrasi data, memproses dan menyimpan serta mendistribusikan informasi. (Awalin 2012)

\section{B. $\quad$ Sistem Terintegrasi}

Sistem Terintegrasi atau sering disebut juga Integrated Enterprise merupakan tugas untuk membuat agar aplikasiaplikasi yang bekerja pada berbagai platform di lokasi yang berbeda dapat bekerja sama guna menghasilkan suatu kesatuan fungsionalitas, sehingga dapat saling berbagi informasi, layanan dan proses bisnis baik di dalam enterprise maupun antar enterprise. (Kristanti 2012)

\section{C. $\quad$ Android}

Android merupakan Sistem operasi yang gratis dan terbuka dari google yang berjalan diberbagai perangkat seperti telepon, tablet bahkan televisi. Terdapat banyak perangkat yang dapat digunakan dengan satu platform. Aplikasi Android dapat dibangun pada Sistem Operasi Mac, Windows, dan Unix. Selain itu kita dapat mempublikasikan aplikasi yang kita bangun secara langsung tanpa perlu disetujui oleh siapapun. 
Aplikasi Android memisahkan Visual Definition aplikasi(Seperti XML Layout dan String Resource) dari Tingkah Laku atau Tindakan yang didefinisikan pada Kode Java.

Aplikasi Android secara Native dibangun menggunakan bahasa pemrogramman Java, namun pada perkembangannya kita dapat menggunakan bahasa pemrogramman berbasis Web dimana ini dimungkinkan dengan memanfaatkan Web View yang ada pada Android. (Simon 2011)

Dalvik Virtual Machine (DVM) merupakan satu elemen kunci dari Android. Android berjalan di dalam DVM bukan di Java Virtal Machine (JVM). DVM adalah "register based" sementara JVM adalah "stack based". (ARIZA 2014)

\section{Java}

Bahasa pemrogramman Java memiliki Syntax yang bersahabat, menawarkan fitur berbasis Object, Manajemen memori, serta Portability yang baik. Write-Once Run-Anywhere menjadi kelebihan dari Java. Program java akan dijalankan pada Java Virtual Machine(JVM). JVM akan mengubah bytecode menjadi kode yang dapat dimengerti oleh platform kemudian menjalankan programnya. (Sierra \& Bates 2005)

Ada 4 (empat) prinsip dasar dari pemrograman berorientasi obyek, yaitu abstraksi, enkapsulasi, modularitas dan hirarki. Berikut dijelaskan satu persatu secara singkat.

1. Abstraksi memfokuskan perhatian pada karakteristik obyek yang paling penting dan paling dominan yang bisa digunakan untuk membedakan obyek tersebut dari obyek lainnya.

2. Enkapsulasi menyembunyikan banyak hal yang terdapat dalam obyek yang tidak perlu diketahui oleh obyek lain. Dalam praktek pemrograman, enkapsulasi diwujudkan dengan membuat suatu kelas interface yang akan dipanggil oleh obyek lain, sementara didalam obyek yang dipanggil terdapat kelas lain yang mengimplementasikan apa yang terdapat dalam kelas interface.

3. Modularitas membagi sistem yang rumit menjadi bagianbagian yang lebih kecil yang bisa mempermudah developermemahami dan mengelola obyek tersebut.

4. Hirarki berhubungan dengan abstraksi dan modularitas, yaitu pembagian berdasarkan urutan dan pengelompokkan tertentu. Misalnya untuk menentukan obyek mana yang berada pada kelompok yang sama, obyek mana yang merupakan komponen dari obyek yang memiliki hirarki lebih tinggi. Semakin rendah hirarki obyek berarti semakin jauh abstraksi dilakukan terhadap suatu obyek. (Haviluddin 2011)

\section{E. $\quad P H P$}

PHP Pertama kali ditemukan pada 1995 oleh seorang Software Developer bernama Rasmus Lerdrof. Ide awal PHP adalah ketika itu Radmus ingin mengetahui jumlah pengunjung yang membaca resume online-nya. script yang dikembangkan baru dapat melakukan dua pekerjaan, yakni merekam informasi pengunjung, dan menampilkan jumlah pengunjung dari suatu website. Dan sampai sekarang kedua tugas tersebut masih tetap populer digunakan oleh dunia web saat ini. Kemudian, dari situ banyak orang di milis mendiskusikan script buatan Rasmus Lerdrof, hingga akhirnya rasmus mulai membuat sebuah tool/script, bernama Personal Home Page (PHP). (Dwiartara 2012)

PHP dibangun dari scripts yang ditulis secara plaintext. PHP Interpreter adalah bagian dari perangkat lunak yang ada pada Web Server, yang membaca file tersebut dan mengartikannya, memberikan keluaran HTML dan petunjuk mengenai bagaimana perilaku yang ada maupun menginterpretasikan masukan dari pengguna. (McLaughlin 2012)

\section{F. $\quad H T M L$}

HTML atau HyperText Markup Language, adalah suatu cara memberikan tanda yang memberikan perintah kepada browser bagaimana suatu teks terstruktur. HMTL memberikan perintah kepada browser bagaimana struktur dari dokumen kita, bagaimana heading-nya, bagaimana paragrafnya, bagaimana suatu teks akan ditampilkan, dan lainnya. Dengan informasi yang diberikan, browsers dibangun dengan perintah dasar bagaimana menampilkan setiap elemen yang ada. (Elisabeth \& Eric 2012)

\section{G. $\quad C S S$}

CSS atau Cascading Style Sheet adalah bahasa pemrogramman yang digunakan untuk mendeskripsikan bagaimana suatu konten akan ditampilkan. Kita memberikan karakteristik tampilan dari elemen yang ada pada HTML menggunakan CSS. (Elisabeth \& Eric 2012)

Kode CSS dapat dituliskan dengan tiga cara yaitu inline, internal dan external. Ketiganya bisa anda lakukan sesuai dengan kebutuhan. (Ariona 2013)

\section{H. Javascript}

Javascript menjadikan suatu web lebih interaktif, ini menjadikannya bisa mengerti yang kita butuhkan, memroses masukkan pengguna, serta memberikan respon yang lebih baik.

Javascript digunakan bersama dengan HTML dan CSS sebagai salah satu dari tiga Modern Web Page Construction. HTML menyediakan struktur, CSS memberikan tampilan, dan JavaScripts menjalankannya dan membuat perintah berjalan. (Morrison 2007)

Javascript dikembangkan oleh Brendan Eich di Netspace pada tahun 1995-1996. Dulu disebut dengan LiveScript. Javascript bukanlah bahasa yang di-compile, ini membuatnya terlihat serta terasa memiliki banyak kelebihan.

Javascript pada awalnya terfokus pada sisi pengguna sebagai Form-Validation, dan digunakan dengan gambar untuk menyempurnakannya, lebih membantu, membuatnya lebih interaktif serta memberikan umpan balik bagi pengunjung. (Suehring n.d.)

\section{JQuery}

JQuery merupakan Javascript Library yang cepat, kecil, dan memiliki banyak feature. JQuery membuat sesuatu seperti HTML Document Traversal dan Manipulation, Event Handling, Animation, dan AJAX menjadi lebih sederhana dengan API yang mudah digunakan diberbagai browser. (jquery.com n.d.)

\section{J. JQuery Mobile}

JQuery adalah HTML5-based user interface yang merupakan Framework yang digunakan untuk melakukan desain responsive website atau aplikasi yang dijalankan pada banyak perangkat seperti smartphone, tablet, dan desktop platform. (Jquerymobile.com n.d.)

\section{K. $\quad M y S Q L$}

Basisdata adalah suatu tools yang digunakan untuk menyimpan informasi, mengambil informasi kapanpun dibutuhkan, dan mengatur informasi yang tersimpan. Jika digambarkan Lemari File merupakan suatu basisdata. (McLaughlin 2012)

Database Management System atau DBMS merupakan suatu perangkat lunak yang digunakan untuk membuat, memelihara, mengontrol, dan mengakses basisdata secara praktis dan efisien. Sedangkan RDBMS atau Relationship DBMS merupakan salah satu DBMS yang mendukung adanya Relasi atau hubungan antar tabel. 


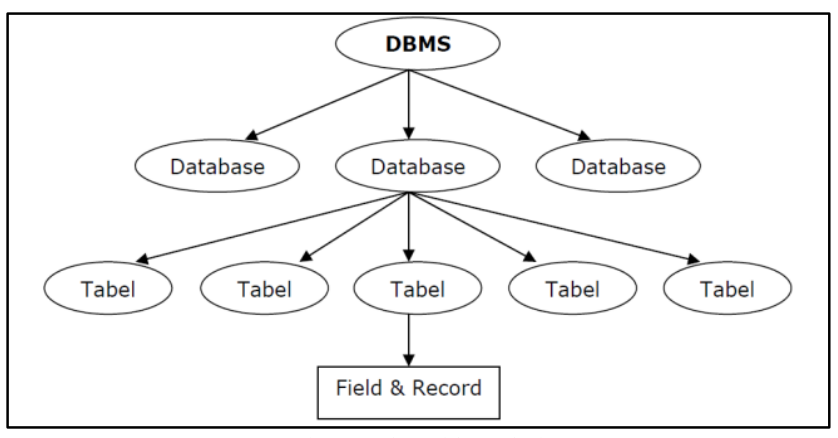

Gambar 1 Hierarki Basisdata.

Terdapat 3 (tiga) jenis perintah SQL, yaitu :

1. DDL atau Data Definition Language

DDL merupakan perintah SQL yang berhubungan dengan pendefinisian suatu struktur database, dalam hal ini database dan table. Beberapa perintah dasar yang termasuk DDL ini antara lain CREATE, ALTER, RENAME, DROP.

\section{DML atau Data Manipulation Language}

DML merupakan perintah SQL yang berhubungan dengan manipulasi atau pengolahan data atau record dalam tabel. Perintah SQL yang termasuk dalam DML antara lain SELECT, INSERT, UPDATE, DELETE.

\section{DCL atau Data Control Language}

DCL merupakan perintah SQL yang berhubungan dengan manipulasi user dan hak akses (priviledges). Perintah SQL yang termasuk dalam DCL antara lain GRANT, REVOKE. (Solichin 2010)

\section{Rapid Application Development}

Rapid Application Development (RAD) adalah salah satu metode pengembangan suatu sistem informasi dengan waktu yang relatif singkat. Untuk pengembangan suatu sistem informasi yang normal membutuhkan waktu minimal 180 hari, akan tetapi dengan menggunakan metode RAD suatu sistem dapat diselesaikan hanya dalam waktu 30-90 hari.

Adapun kelemahan-kelemahan yang terdapat pada metode konvensional adalah sebagai berikut:

- Dengan metode konvensional, maka terdapat batas waktu yang cukup lama mulai dari pembuatan sistem sampai dengan konsumen dapat menggunakan sistem tersebut.

- Dengan metode konvensional, apabila proses pengembangan suatu sistem membutuhkan waktu yang lama maka kebutuhan konsumen pada sistem akan mengalami perubahan seiring dengan perubahan proses bisnis yang dilakukan oleh konsumen.

- Dengan metode konvensional, sistem yang dikembangkan tidak akan mempunyai manfaat apabila belum diselesaikan seluruhnya.

Pada saat mengembangkan suatu sistem pasti dihadapkan dengan 3 pilihan model yaitu:

- Efficient Development (model pengembangan yang mengutamakan schedule, ekonomi dan kualitas produk secara seimbang). Schedule lebih cepat dari rata-rata. Ekonomi, biaya lebih murah dari rata-rata. Produk lebih baik daripada kualitas rata-rata.

- Sensible RAD (model pengembangan yang mengutamakan schedule dibandingkan dengan ekonomi dan kualitas produk). Schedule lebih cepat dari rata-rata. Ekonomi, biaya lebih murah sedikit dari rata-rata. Produk lebih baik sedikit dari kualitas rata-rata.

- All-out RAD (model pengembangan yang mengutamakan schedule dengan mengorbankan ekonomi dan kualitas produk). Schedule paling cepat. Ekonomi biaya lebih mahal dari rata-rata. Produk lebih buruk dari kualitas ratarata.

Jurnal Teknologi dan Sistem Komputer, Vol.3, No.2, April 2015 (e-ISSN: 2338-0403)
Dengan menggunakan RAD maka ada satu atau beberapa tujuan berikut ini yang tidak akan dapat dicapai secara bersamasama yaitu:

- Kemungkinan terjadi kesalahan yang kecil, karena pihak pengembang tidak mempunyai hak untuk mengubah komponen- komponen yang digunakan dalam mengembangkan suatu sistem.

- Tingkat kepuasan konsumen yang tertinggi, karena kebutuhan-kebutuhan sekunder dari konsumen harus dikorbankan supaya suatu sistem dapat diselesaikan sesuai jadwal.

- Biaya pengembangan yang termurah, karena dengan menggunakan komponen yang sudah ada dapat menyebabkan biaya yang lebih besar apabila dibandingkan dengan mengembangkan komponen sendiri.

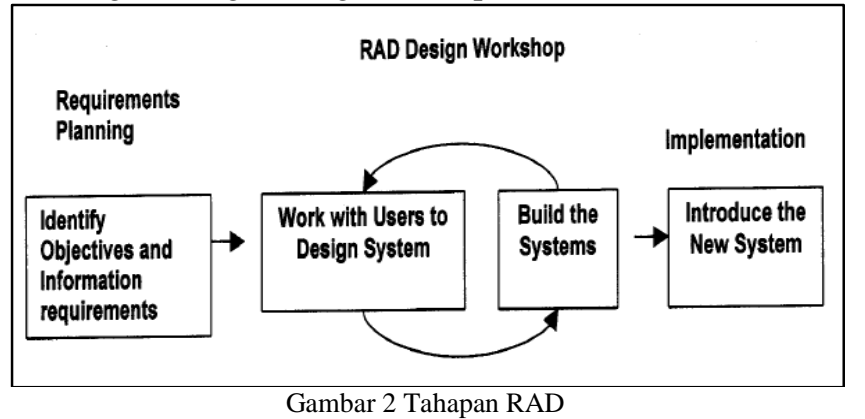

Metode RAD mempunyai 3 tahapan utama seperti yang terlihat pada gambar 2. Berikut merupakan tahapannya :

1. Rencana Kebutuhan (Requirement Planning)

Pada tahap ini, user dan analyst melakukan semacam pertemuan untuk melakukan identifikasi tujuan dari aplikasi atau sistem dan melakukan identifikasi kebutuhan informasi untuk mencapai tujuan. Pada tahap ini hal terpenting adalah adanya keterlibatan dari kedua belah pihak, bukan hanya sekedar persetujuan akan proposal yang sudah dibuat. Untuk lebih jauh lagi, keterlibatan user bukan hanya dari satu tingkatan pada suatu organisasi, melainkan beberapa tingkatan organisasi sehingga informasi yang dibutuhkan untuk masingmasing user dapat terpenuhi dengan baik.

2. Proses Desain (Design Workshop)

Pada tahap ini adalah melakukan proses desain dan melakukan perbaikan perbaikan apabila masih terdapat ketidaksesuaian desain antara user dan analyst. Untuk tahap ini maka keaktifan user yang terlibat sangat menentukan untuk mencapai tujuan, karena user bisa langsung memberikan komentar apabila terdapat ketidaksesuaian pada desain. Biasanya, user dan analyst berkumpul menjadi satu dan duduk di meja melingkar dimana masing-masing orang bisa melihat satu dengan yang lain tanpa ada halangan.

3. Implementasi (Implementation)

Setelah desain dari sistem yang akan dibuat sudah disetujui baik itu oleh user dan analyst, maka pada tahap ini programmer mengembangkan desain menjadi suatu program. Setelah program selesai baik itu sebagian maupun secara keseluruhan, maka dilakukan proses pengujian terhadap program tersebut apakah terdapat kesalahan atau tidak sebelum diaplikasikan pada suatu organisasi. Pada saat ini maka user bias memberikan tanggapan akan sistem yang sudah dibuat serta persetujuan mengenai sistem tersebut.

\section{Tahapan Keseluruhan}

Dengan berdasarkan pada tahapantahapan tersebut di atas maka proses utama pengembangan suatu sistem dengan menggunakan metode RAD adalah sebagai berikut :

- $\quad$ Pengembang membuat prototype berdasarkan kebutuhan-

kebutuhan yang sudah didefinisikan sebelumnya

Desainer melakukan penilaian terhadap prototype 
- User melakukan uji coba pada prototype dan memberikan masukan mengenai kebutuhan-kebutuhan yang kurang.

- User dan developer melakukan pertemuan untuk memberikan penilaian terhadap produk secara bersamasama, menyesuaikan kebutuhan serta memberikan komentar apabila diperlukan perubahan.

- Semua kebutuhan akan sistem dan perubahan-perubahan yang terjadi dilakukan proses "timeboxed" dengan mempunyai 2 kemungkinan yaitu perubahan yang tidak dapat ditampung seperti yang sudah direncanakan harus dihilangkan, dan Jika diperlukan, kebutuhan-kebutuhan yang bersifat sekunder ditiadakan.

Beberapa keuntungan dalam menggunakan metode RAD adalah sebagai berikut:

- Membeli sistem yang baru memungkinkan untuk lebih menghemat biaya ketimbang mengembangkan sendiri.

- Proses pengiriman menjadi lebih mudah, hal ini dikarenakan proses pembuatan lebih banyak menggunakan potonganpotongan script.

- Mudah untuk diamati karena menggunakan model prototype, sehingga user lebih mengerti akan sistem yang dikembangkan.

- Lebih fleksibel karena pengembang dapat melakukan proses desain ulang pada saat yang bersamaan.

- $\quad$ Bisa mengurangi penulisan kode yang kompleks karena menggunakan wizard.

- Keterlibatan user semakin meningkat karena merupakan bagian dari tim secara keseluruhan.

- Mampu meminimalkan kesalahan-kesalahan dengan menggunakan alat-alat bantuan (CASE tools).

- Mempercepat waktu pengembangan sistem secara keseluruhan karena cenderung mengabaikan kualitas.

- Tampilan yang lebih standar dan nyaman dengan bantuan software-software pendukung.

Selain itu dalam penggunaannya terdapat kerugian dalam menggunakan metode RAD, seperti berikut :

- Dengan melakukan pembelian belum tentu bisa menghemat biaya dibandingkan dengan mengembangkan sendiri.

- Membutuhkan biaya tersendiri untuk membeli peralatanperalatan penunjang seperti misalnya software dan hardware.

- Kesulitan melakukan pengukuran mengenai kemajuan proses.

- Kurang efisien karena apabila melakukan pengkodean dengan menggunakan tangan bisa lebih efisien.

- Ketelitian menjadi berkurang karena tidak menggunakan metode yang formal dalam melakukan pengkodean.

- Lebih banyak terjadi kesalahan apabila hanya mengutamakan kecepatan dibandingkan dengan biaya dan kualitas.

- Fasilitas-fasilitas banyak yang dikurangi karena terbatasnya waktu yang tersedia.

- $\quad$ Sistem sulit diaplikasikan di tempat yang lain.

- Fasilitas yang tidak perlu terkadang harus disertakan, karena menggunakan komponen yang sudah jadi, sehingga hal ini membuat biaya semakin meningkat karena harga komponen yang lebih lengkap semakin mahal. (Noertjahyana 2002)

\section{PERANCANGAN SISTEM}

\section{A. Tahap Pengembangan Sistem}

Tahapan yang digunakan pada pembuatan sistem adalah Rapid Application Dexelopment (RAD). Pada Gambar 3 ditunjukkan bahwa RAD memiliki tiga tahapan utama, yaitu Rencana Kebutuhan (Requirement Planning), Proses Desain (Desain Workshop), dan Implementasi (Implementation). Sedangkan pada tahap Proses Desain dibagi lagi menjadi dua hal yaitu Desain Sistem (Design System) dan Membangun Sistem (Build System).

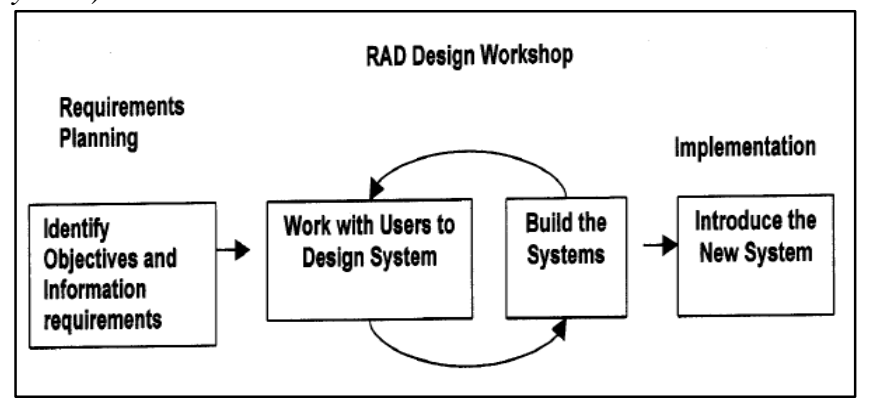

Gambar 3 Tahapan Desain RAD

- Rencana Kebutuhan.

Pada tahap ini akan dilakukan perencanaan terhadap kebutuhan sistem secara menyeluruh baik proses kerja maupun kebutuhan-kebutuhan yang diperlukan oleh pengguna. Pada tahap ini analisis terhadap sistem diperlukan untuk memilah antara kebutuhan pokok dan kebutuhan sekunder, ini diperlukan karena pada metodologi desain RAD yang ingin dicapai adalah kecepatan pembuatan produk, atau dengan kata lain waktu menjadi indikator utama dalam metodologi ini, selain waktu ada juga indikator lain seperti biaya serta kualitas dari produk itu sendiri.

- Proses Desain.

Proses desain dilakukan oleh pengembang bersama dengan pengguna, salah satu kelebihan dari metodologi ini adalah pengguna dilibatkan langsung dalam proses pembuatan sistem, ini membuat sistem yang dibuat lebih memenuhi proses kerja (bussiness process) yang dilakukan oleh pengguna, sehingga dapat memberikan kepuasan kepada pengguna.

Pada tahap desain sistem ini akan dilakukan beberapa desain, seperti basisdata menggunakan Entity Relationship Diagram, kemudian untuk melakukan desain proses kerja akan digunakan Sequence Diagram dan Use Case Diagram, serta pembuatan tampilan dasar dari aplikasi.

- Implementasi.

Tahap ini dilakukan setelah desain sistem disepakati oleh pengguna dan pengembang. Pada tahap ini pengembang akan menindak lanjuti desain sistem yang telah disetujui kedalam suatu sistem yang siap digunakan secara nyata. Setelah sistem selesai dibuat, akan dilakukan pengujian terhadap sistem. Keterlibatan pengguna dalam pengujian merupakan bagian penting yang memberikan kepuasan terhadap pengguna. Pada sistem ini akan dilakukan pengujian secara White Box atau Kotak Putih, yang artinya sistem akan diuji pada fungsi-fungsi yang ada apakah sudah sesuai dengan fungsinya, apakah sistem sudah bekerja seperti seharusnya.

\section{B. Rencana Kebutuhan}

Rencana kebutuhan merupakan tahapan yang sangat penting karena pada tahap ini dilakukan perencanaan terhadap sistem, baik perilakunya, fungsi-fungsi yang diinginkan dan pengelompokkan terhadap fitur-fitur yang harus ada dan fiturfitur tambahan.

Dari perencanaan kebutuhan tersebut dapat digambarkan secara umum sistem yang akan dibuat dengan menggunakan UML, UML yang digunakan adalah UML versi 1.1 dimana terdapat delapan diagram (Use Case, Activity, Sequence, Collaboration, Class, Statechart, Component, Deployment) yang memiliki fungsi-fungsi yang berbeda dalam menggambarkan, suatu sistem. Dalam JTsiskongam-323arkan 
kebutuhan sistem digunakan Use Case Diagram, untuk kebutuhan dari aplikasi ini dapat dilihat pada Gambar 4 yang menggambarkan Use Case Diagram dari aplikasi pendataan barang ini.

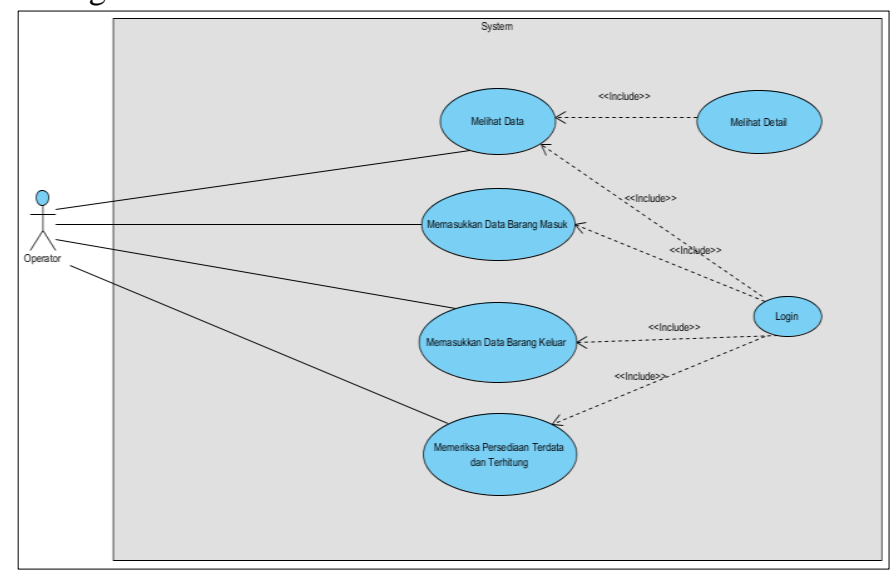

Gambar 4 Use Case Diagram Sistem

Pada Gambar 4 dapat dilihat terdapat satu actor yaitu Operator, Operator dalam konteks aplikasi ini merupakan orang yang bertanggung jawab terhadap pendataan barang, dengan kata lain Operator merupakan pengguna utama dari sistem ini. Kemudian, terdapat enam Use Case yaitu melihat data, memasukkan data barang masuk, memasukkan data barang keluar, memeriksa persediaan terdata dan terhitung, melihat detail dan login.

\section{Proses Desain}

Proses desain merupakan proses yang dilakukan setelah perencanaan kebutuhan dilakukan, ini dikarenakan dalam melakukan desain terhadap suatu sistem pasti seorang analis harus mengetahui spesifikasi atau kebutuhan dari sistem itu sendiri. Dalam melakukan desain sistem terdapat beberapa hal yang harus dibuat antara lain desain proses kerja (bussiness process), desain penyebaran sistem (Deployment Design), desain basisdata (Database Design), serta desain tampilan (Layout Design).

- Desain Proses Kerja

Desain proses kerja merupakan desain mendasar mengenai perilaku sistem dan aktivitas yang terjadi ketika aplikasi dijalankan. Aktivitas serta perilaku aplikasi ini digambarkan dalam beberapa Activity Diagram.

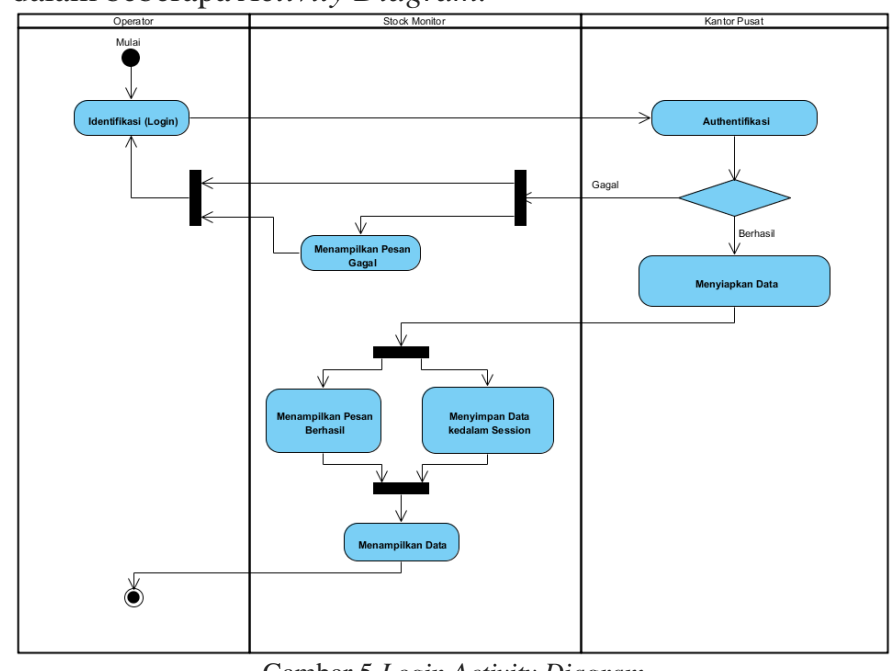

Gambar 5 Login Activity Diagram

Login Activity Diagram yang terdapat pada Gambar 5 menggambarkan tentang bagaimana proses yang akan terjadi ketika seorang Operator masuk ke dalam Aplikasi ini.

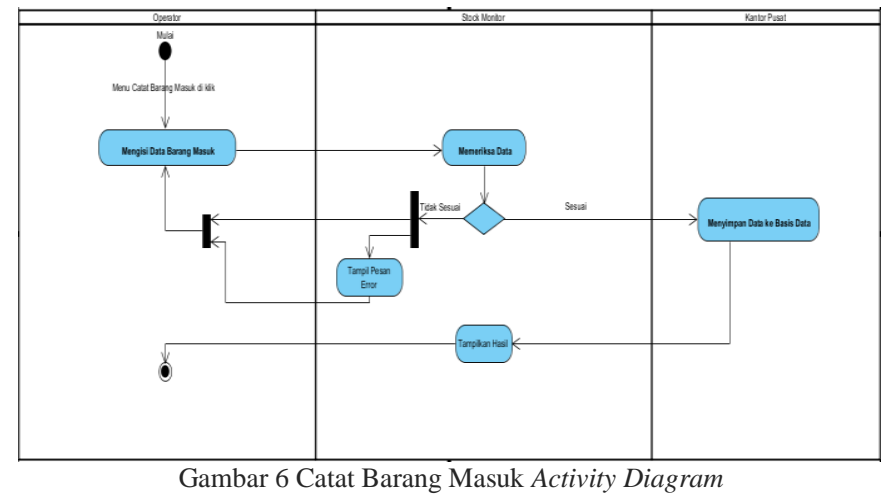

Proses pendataan barang masuk dapat dilihat pada Gambar 6 dapat terlihat setelah Operator menekan menu Catat Barang Masuk.

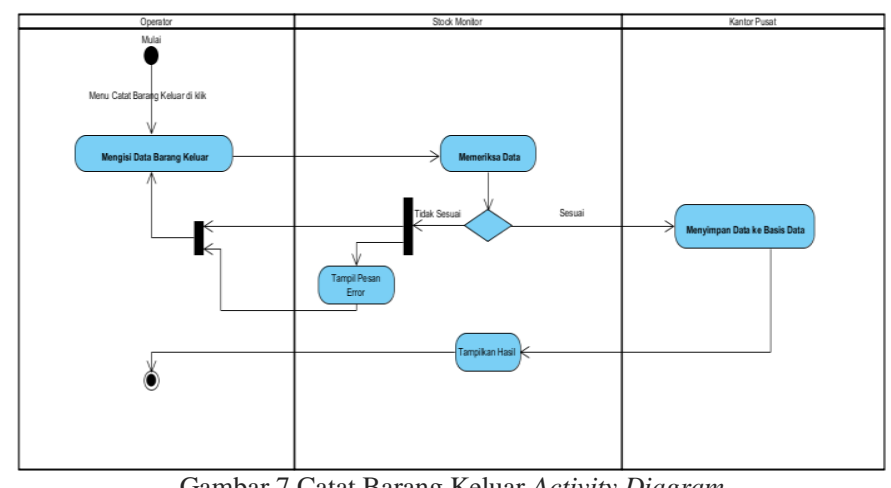

Pada Gambar 7 digambarkan bagaimana proses yang terjadi ketika Operator melakukan pencatatan data karang keluar. Setelah pengguna menekan menu "Catat Barang Keluar. Terlihat bahwa aktivitas ini mirip dengan aktivitas pada pencatatan data barang masuk.

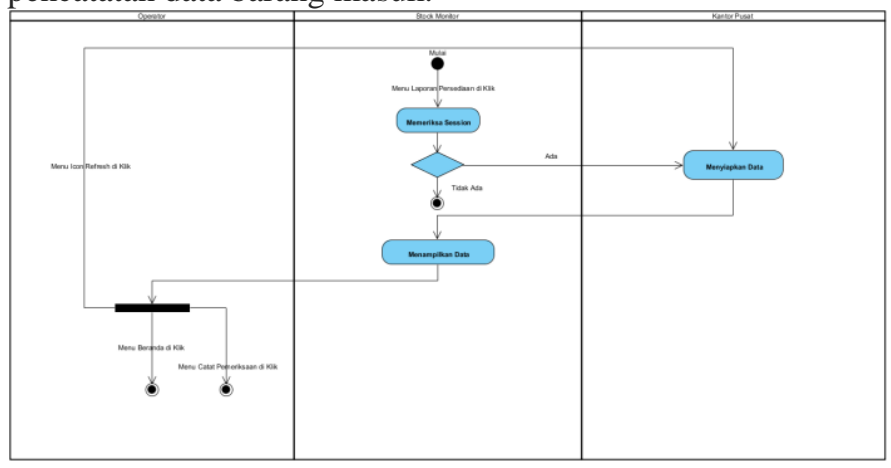

Gambar 8 Laporan Persediaan Activity Diagram

Aktivitas selanjutnya digambarkan menjadi dua buah Activity Diagram, yang pertama menjelaskan mengenai aktivitas perpindahan ke halaman "Laporan Persediaan", yang kedua menjelaskan mengenai aktivitas pencatatan persediaan terhitung. Pada Gambar 8 dapat dilihat ketika pengguna menekan menu "Laporan Persediaan" maka pengguna dialihkan ke halaman "Laporan Persediaan".

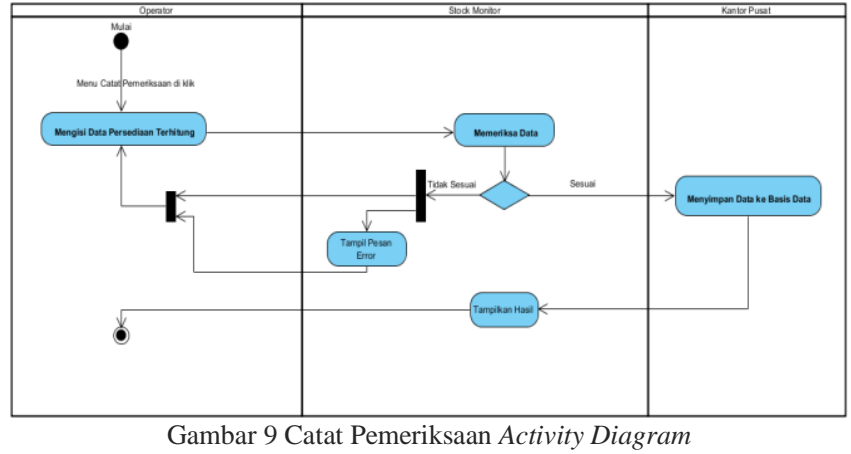


Aktivitas selanjutnya adalah melakukan pencatatan data persediaan barang terhitung yang dapat dilihat pada Gambar 9. Proses pada aktivitas ini mirip dengan proses yang ada pada pencatatan barang keluar dan masuk.

Selanjutnya untuk memberikan gambaran yang lebih jauh mengenai proses yang dilakukan oleh aplikasi akan digambarkan proses-proses yang terjadi dengan Sequence Diagram.

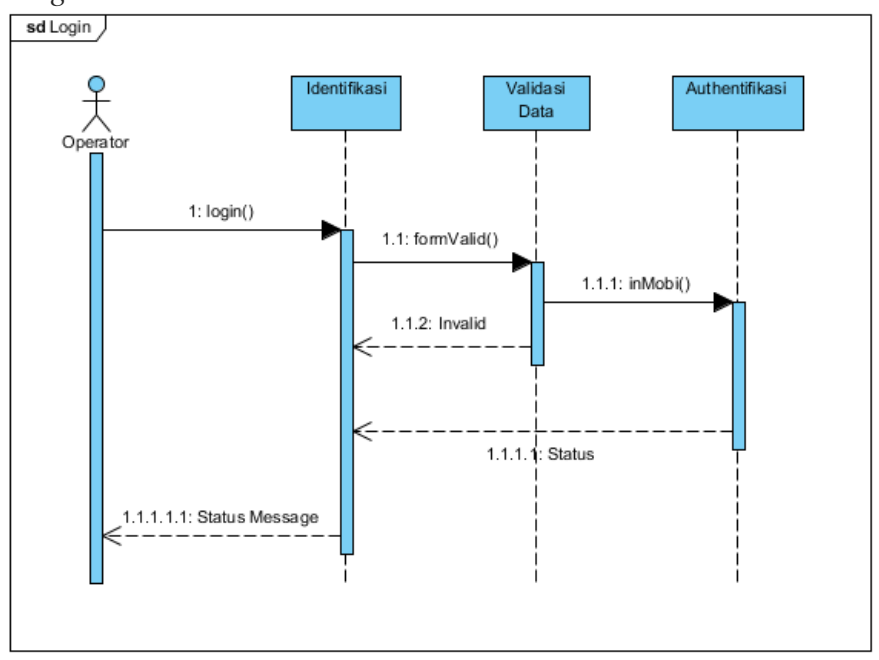

Gambar 10 Login Sequence Diagram

Pada Gambar 10 menggambarkan mengenai proses yang terjadi pada saat Login. Pada halaman utama nanti terdapat tiga sequence, yaitu catat barang masuk, catat barang keluar, dan catat laporan persediaan.

Proses yang terjadi ketika melakukan pendataan barang masuk dapat dilihat pada Gambar 11.

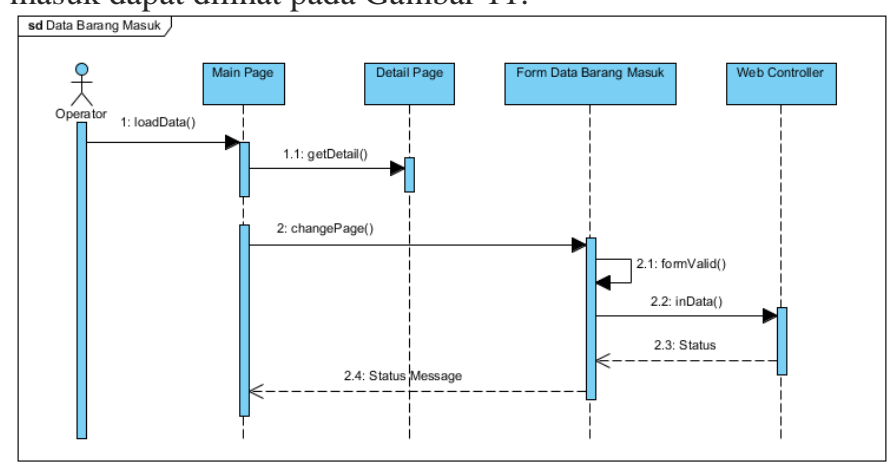

Gambar 11 Catat Barang Masuk Sequence Diagram

Dalam proses pendataan barang keluar dapat dilihat pada Gambar 12.

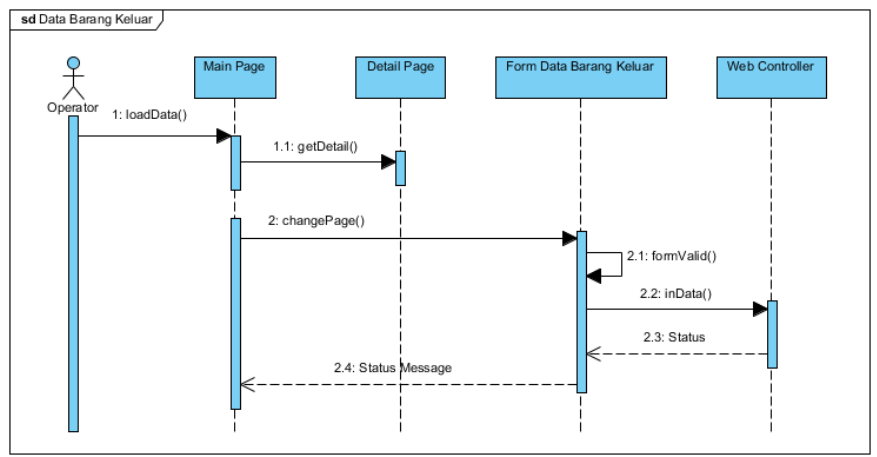

Gambar 12 Catat Barang Keluar Sequence Diagram

Proses yang ada pada pengelolaan laporan persediaan dapat dilihat pada Gambar 13.

Selanjutnya jika pengguna menekan laporan pemeriksaan pada halaman utama laporan persediaan, pengguna akan dialihkan ke halaman rincian. Halaman rincian memberikan informasi mengenai data pemeriksaan secara keseluruhan per pemeriksaan.

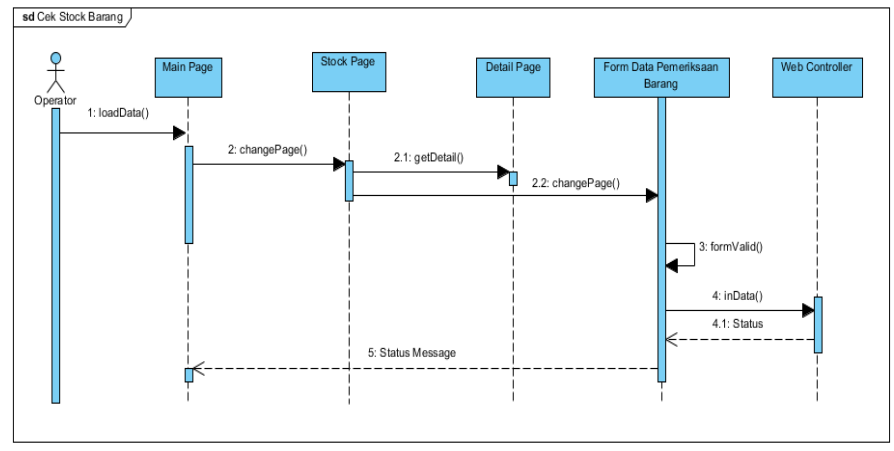

Gambar 13 Laporan Persediaan Sequence Diagram

Laporan persediaan memiliki keterkaitan dengan halaman utama maka pada Sequence Diagram Gambar 3.11 digambarkan saling terkait.

- Desain Penyebaran Sistem

Deployment design merupakan penggambaran bagaimana suatu sistem itu akan dibangun, apa saja yang dibutuhkan untuk membangun sistem tersebut, serta bagaimana antar perangkat sistem tersebut saling terkait. Ditunjukkan desain penyebaran sistem aplikasi pada Gambar 14.

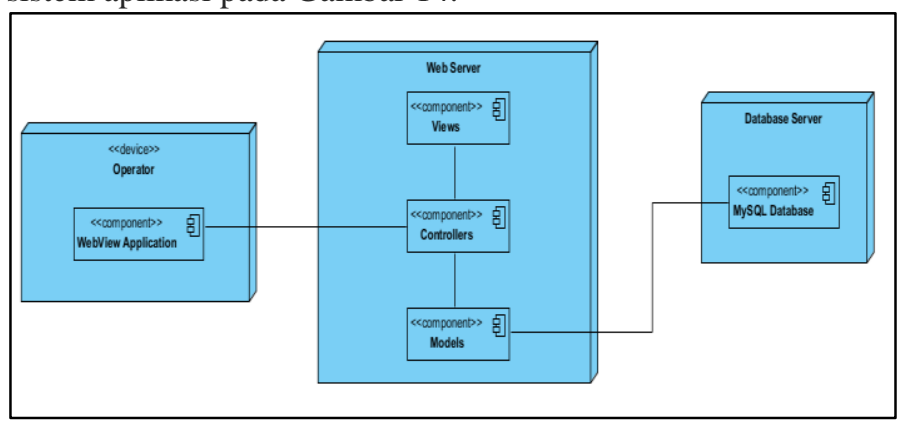

- Desain Basis Data

Pada perancangan perangkat lunak, desain basisdata merupakan suatu tahap yang sangat penting, dimana dalam tahap ini akan dilakukan pembuatan desain dari skema penyimpanan data dari perangkat lunak. Biasanya pembuatan desain basisdata dilakukan dengan membuat gambaran mengenai kebutuhan, serta keterkaitan antar data, gambaran yang digunakan biasanya adalah Entity Relationship Diagram (ERD). Untuk menggambarkan bagaimana basisdata aplikasi pendataan barang ini dibangun, terdapat ERD yang menunjukkan struktur data dari aplikasi yang terdapat pada Gambar 15.

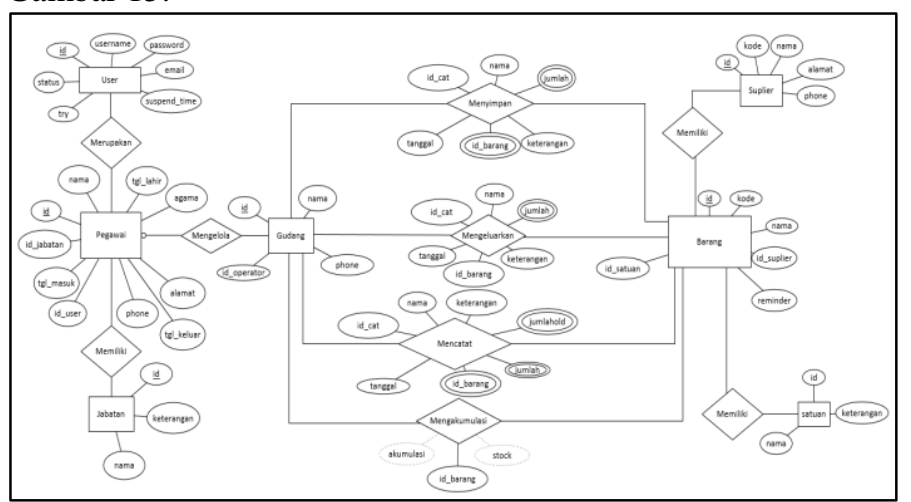

Gambar 15 Entity Relationship Diagram (ERD) Aplikasi

Pada Gambar 15 dapat dilihat keterkaitan antara tabel "Pegawai" dengan tabel "User" dan tabel "Jabatan".

Keterkaitan antara tabel "Pegawai" dengan tabel "Gudang" disini bertujuan agar setiap gudang yang ada memiliki Operator yang bertanggung jawab terhadap gudang itu sendiri pada Gambar 16 ditunjukkan keterkaitan antara keduanya. 


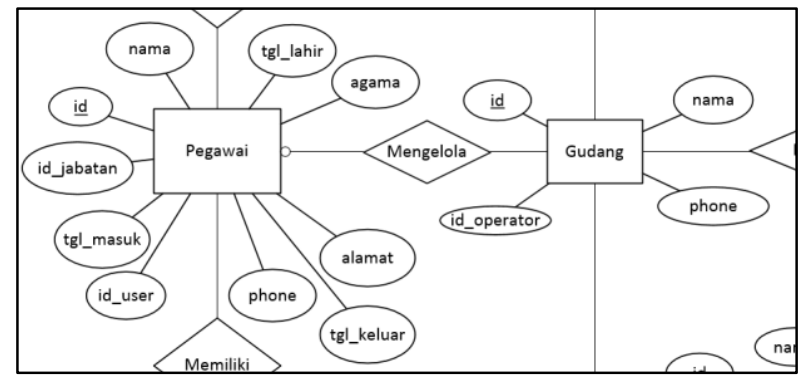

Gambar 16 ERD Keterkaitan Pegawai dan Gudang

Aplikasi ini memiliki tiga fitur utama, yaitu catat barang masuk, catat barang keluar, dan catat pemeriksaan. Dari fitur ini dikelompokkan lagi untuk setiap gudang yang dimiliki, dimana setiap gudang akan memiliki data per barang yang ada. Sehingga dapat disimpulkan bahwa gudang menyimpan data nota masuk, nota keluar, dan laporan persediaan. Pada Gambar 17 dapat dilihat bahwa keterkaitan masing-masing entitas menghasilkan atribut yang dibutuhkan.

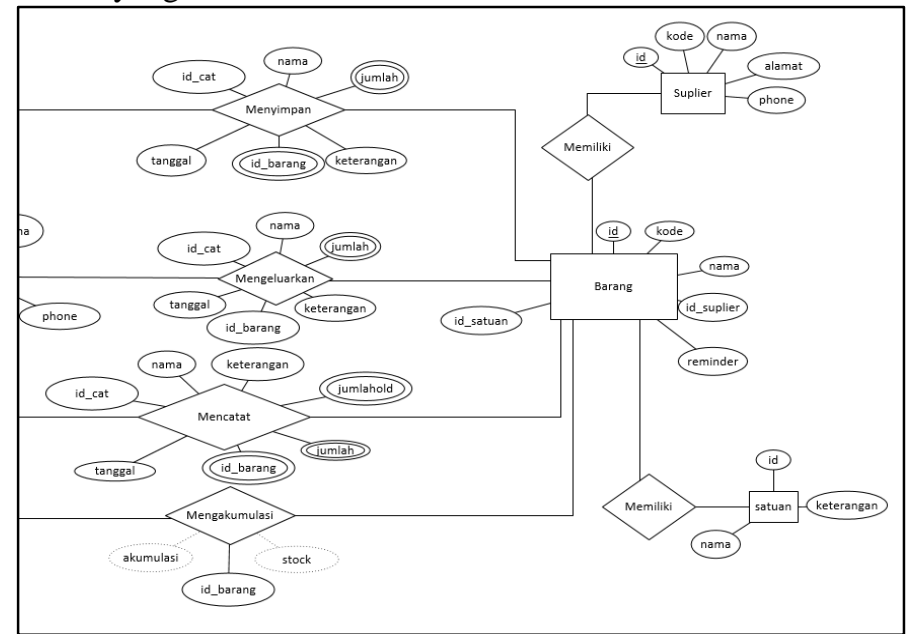

Gambar 17 ERD Keterkaitan Gudang dan Barang

Pada Gambar 18 ditunjukkan keterkaitan antara entitas "Barang", "Suplier", dan "Satuan".

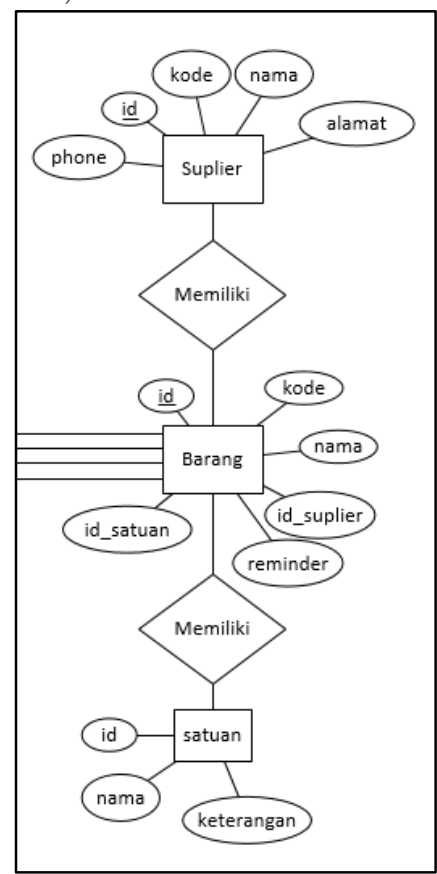

Gambar 18 ERD Keterkaitan Barang, Suplier, dan Satuan

Keterkaitan antara relasi "Menyimpan", relasi "Mengeluarkan", serta relasi "Mencatat" menghasilkan atribut turunan yang dihasilkan dari ketiga relasi tersebut. Keterkaitan antara ketiga relasi ini terlihat pada Gambar 19. Akumulasi barang dihasilkan dari persediaan terdata yaitu jumlah barang yang didata oleh sistem, dikurangi dengan persediaan terhitung. Atribut turunan ini dapat dilihat pada Gambar 20.

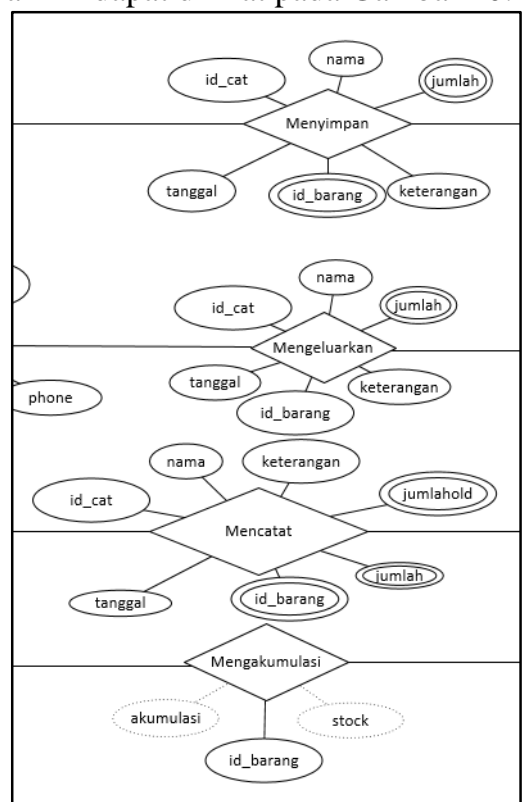

Gambar 19 Relasi "Menyimpan", "Mengeluarkan", "Mencatat”, dan "Mengakumulasi"

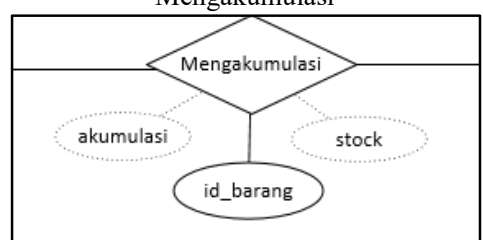

Gambar 20 Atribut Turunan Akumulasi dan Stock

- Desain Tampilan

Desain tampilan merupakan tahapan yang dilakukan berikutnya, desain tampilan bertujuan memberikan gambaran secara umum dari aplikasi yang akan dibangun.

Pada Gambar 21 diperlihatkan desain tampilan halaman login.

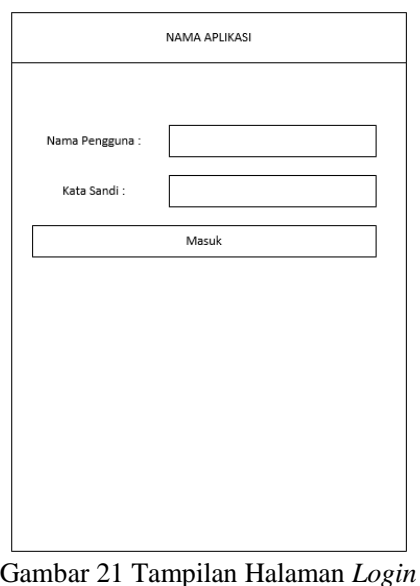

Pada Gambar 22 merupakan tampilan halaman utama dari aplikasi ini.

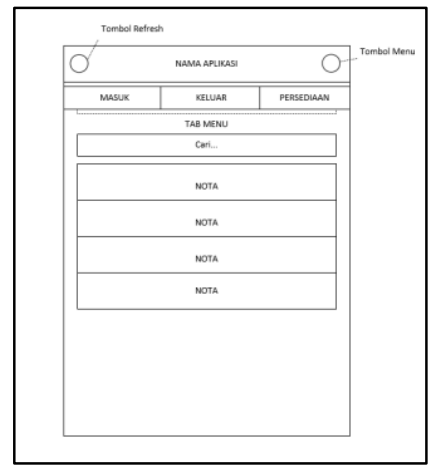

Gambar 22 Tampilan Halaman Utama

JTsiskom - 326 
Terdapat tiga tab menu yang terdapat pada halaman utama, tab тепи "Masuk" dan "Keluar" memiliki tampilan yang sama seperti pada Gambar 22, sedangkan tab menu "Persediaan" memiliki tampilan seperti pada Gambar 23.

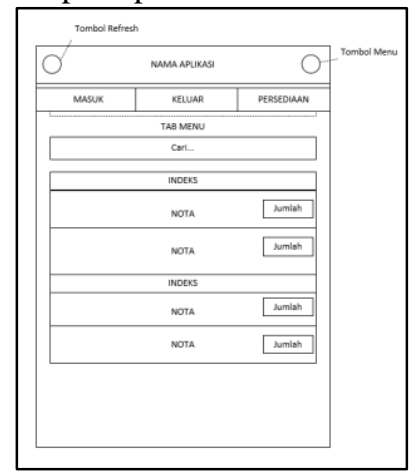

Gambar 23 Tampilan Halaman Tab Menu Persediaan

Pada halaman utama terdapat dua tombol pada bagian header, yaitu tombol "refresh" yang berfungsi untuk mengambil data ulang serta tombol "menu" yang berfungsi untuk menampilkan sidebar menu seperti pada Gambar 24.

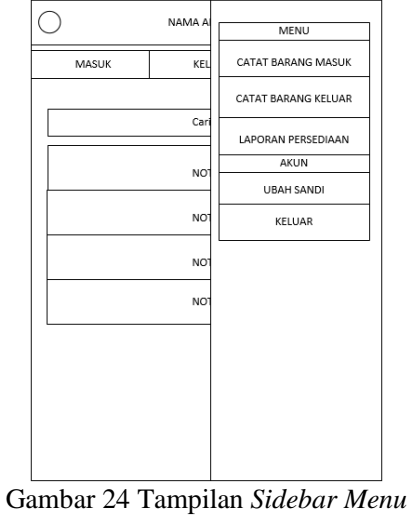

Pada Gambar 25 merupakan pop-up yang muncul ketika "Ubah Sandi" ditekan.

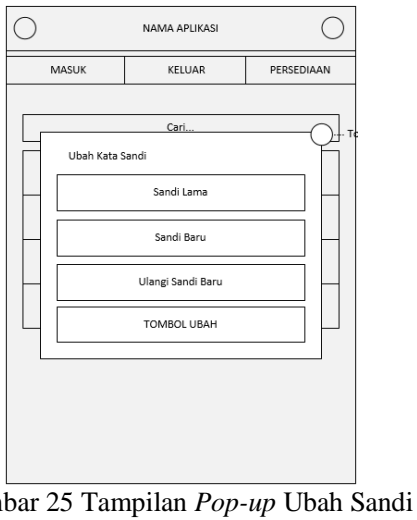

Sedangkan menu "Catat Barang Masuk" dan "Catat Barang Keluar" menuju kehalaman yang sama namun aksi yang dibentuk akan mengikuti variable action yang ada pada Javascript. Tampilan dari form ini ditunjukkan pada Gambar 26.

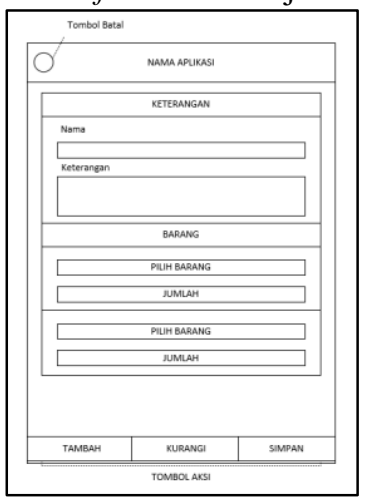

Gambar 26 Tampilan Form Masukkan Data

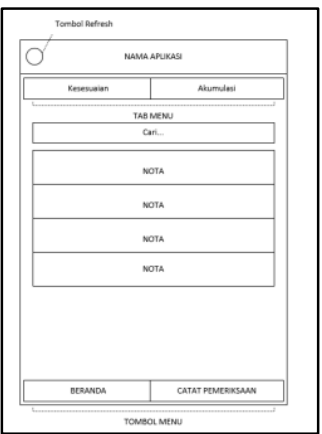

Gambar 27 Tampilan Halaman Laporan Persediaan

Ditunjukkan pada Gambar 27 merupakan desain tampilan dari halaman "Laporan Persediaan", serta "Catat Pemeriksaan" yang digunakan untuk masuk ke form masukkan data seperti pada Gambar 26 namun dengan aksi "cekstock".

Halaman "Detail" ditunjukkan seperti pada gambar 28.

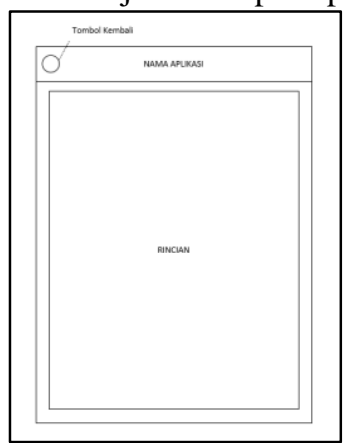

Gambar 28 Tampilan Halaman Rincian Data

Pop-up konfirmasi dapat dilihat pada Gambar 29.

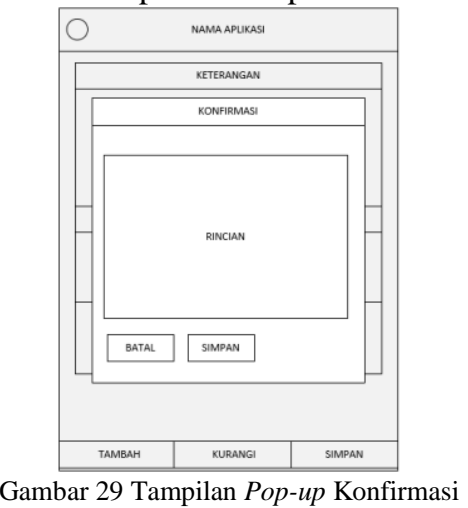

\section{IMPLEMENTASI DAN PENGUJIAN}

\section{A. Tahap Pembuatan}

Pembuatan Aplikasi dilakukan secara terurut berdasarkan kebutuhan dari sistem itu sendiri, oleh karena itu pada pembuatan aplikasi ini yang pertama dibuat adalah Basisdata. Tahap selanjutnya adalah membuat Resource Sharing yang akan digunakan pada sistem informasi yang terintegrasi dengan aplikasi ini.

- Tahap Pembuatan Basisdata

Pembuatan Basis Data dilakukan menggunakan aplikasi pihak ketiga phpmyadmin. Phpmyadmin menyediakan pembuatan basisdata secara GUI, hanya dengan mengetikkan beberapa hal dan memilih beberapa pilihan saja basisdata dapat dibuat. Namun walaupun begitu phpmyadmin juga menyediakan Мепи SQL yang dapat digunakan untuk melakukan eksekusi query langsung ke basisdata.

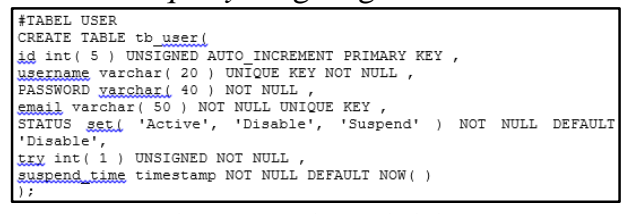

Gambar 30 Membuat tabel tb use 
Pada kode Gambar 30 di atas menunjukkan bagaimana tabel tb_user dibuat.

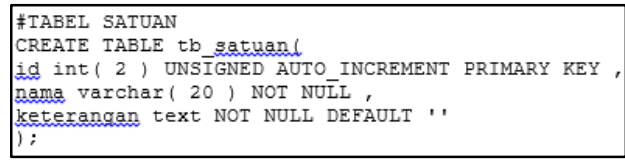

Gambar 31 Membuat tabel tb_satuan

Kode query pada Gambar 31 digunakan untuk membuat tabel yang berisi satuan-satuan dari barang-barang yang ada di gudang.

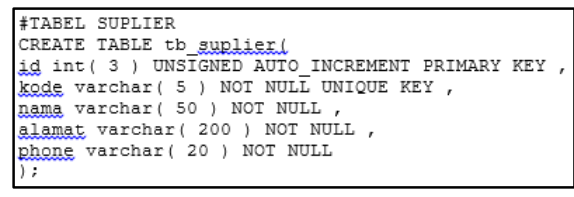

Gambar 32 Membuat tabel tb_suplier

Tabel tb_suplier dibuat dengan menjalankan kode pada Gambar 32.

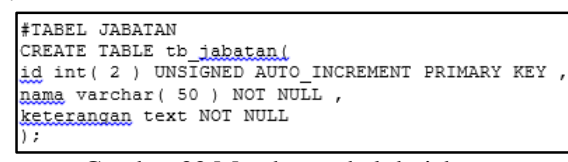

Gambar 33 Membuat tabel tb_jabatan

Tabel tb_jabatan digunakan sebagai acuan untuk melihat level user. Kode query yang digunakan ditunjukkan pada Gambar 33.

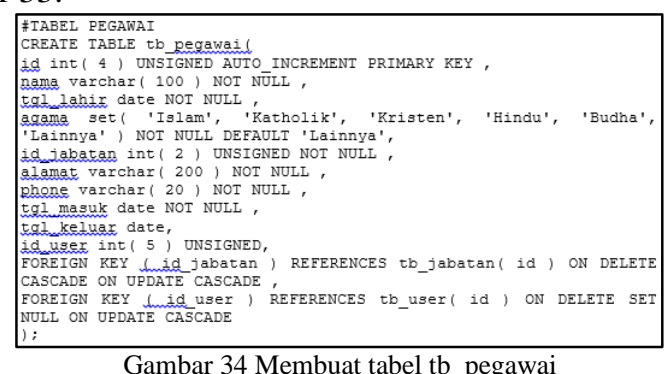

Pada Gambar 34 ditunjukkan kode yang digunakan untuk membuat tabel tb_pegawai.

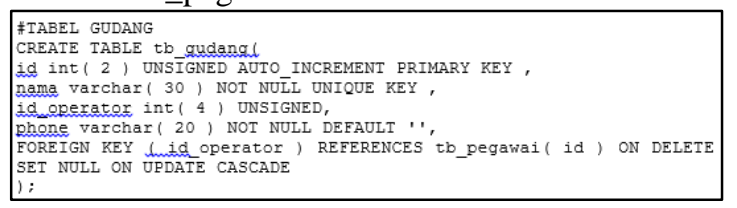

\section{Gambar 35 Membuat tabel tb_gudang}

Tabel gudang dibuat menggunakan kode pada Gambar 35

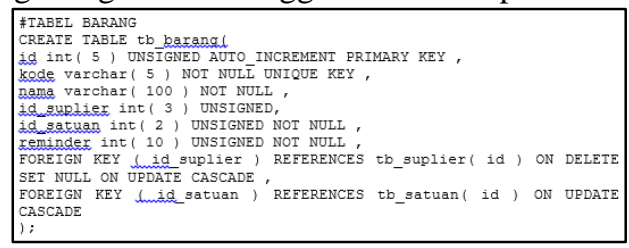

Gambar 36 Membuat tabel tb_barang

Tabel tb_barang digunakan sebagai acuan dari masukkan barang masuk, barang keluar, serta laporan persediaan. Dengan kata lain daftar dari barang-barang yang ada di gudang disimpan pada tabel ini. Untuk membuat tabel tb_barang digunakan kode seperti pada Gambar 36.

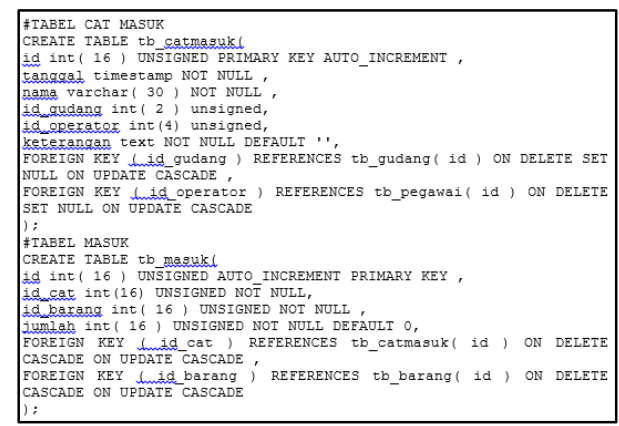

Gampar 37 Membuat tabel tb_catmasuk_dan tb_masuk
Pada Gambar 37 ditunjukkan kode untuk membuat tabel tb_catmasuk dan tabel tb_masuk.

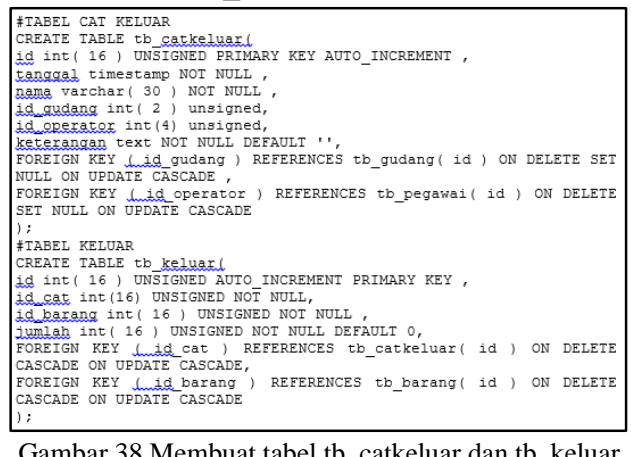

Pada Gambar 39 ditunjukkan kode untuk membuat tabel yang digunakan pada pengolahan data keluar.

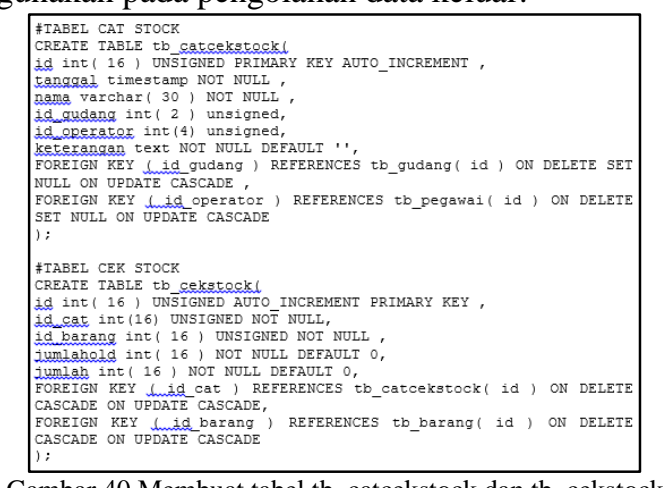

Gambar 40 Membuat tabel tb_catcekstock dan tb_cekstock

Pada Gambar 40 ditunjukkan kode untuk membuat tabel yang dibutuhkan untuk mengolah data laporan persediaan.

Query yang digunakan dieksekusi pada menu $S Q L$ yang ada pada phpMyadmin seperti pada Gambar 41 .

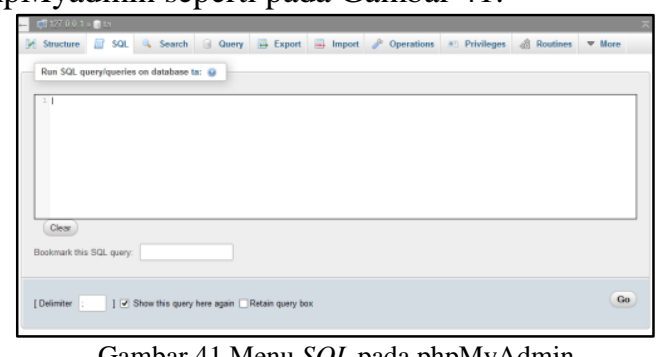

View adalah tabel yang dibuat secara virtual yang sebenarnya merupakan stored query yang nantinya akan dieksekusi ketika sebuah View dipanggil, untuk melihat suatu.

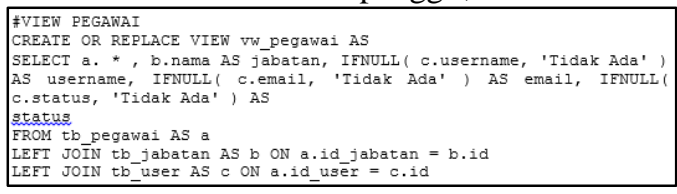

Gambar 42 Membuat view vw_pegawai

View vw_pegawai digunakan untuk menggabungkan data sehingga informasi yang terbentuk dapat digunakan oleh pengguna sistem, view ini dibuat menggunakan kode seperti pada Gambar 42.

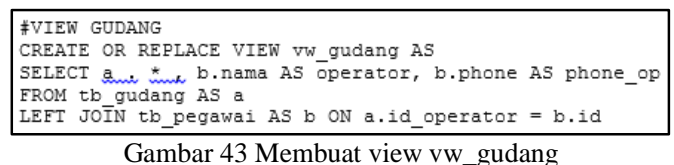

Pada vw_gudang dibuat menggunakan kode seperti pada Gambar 43. 


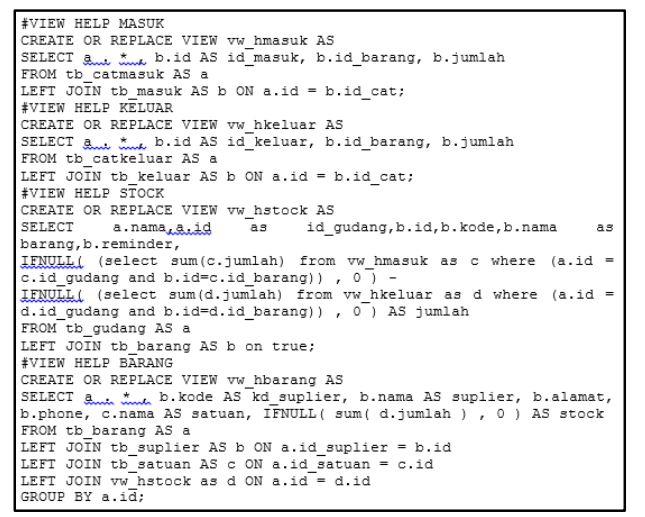

Gambar 44 Membuat view vw_hmasuk, vw_hkeluar, vw_hstock, dan

$$
\text { vw_hbarang }
$$

Kode views pada Gambar 44 digunakan untuk membantu dalam membuat sebuah view yang lebih kompleks lagi. Contoh pada view vw_hstock dibuat agar dapat menghitung nilai persediaan hanya dari data barang keluar-masuk, namun pada tingkat yang lebih jauh, Operator membutuhkan nilai jumlah persediaan yang sudah dikurangi dengan data terhitung (tb_cekstock) sehingga persediaan yang terhitung lebih sesuai atau valid.

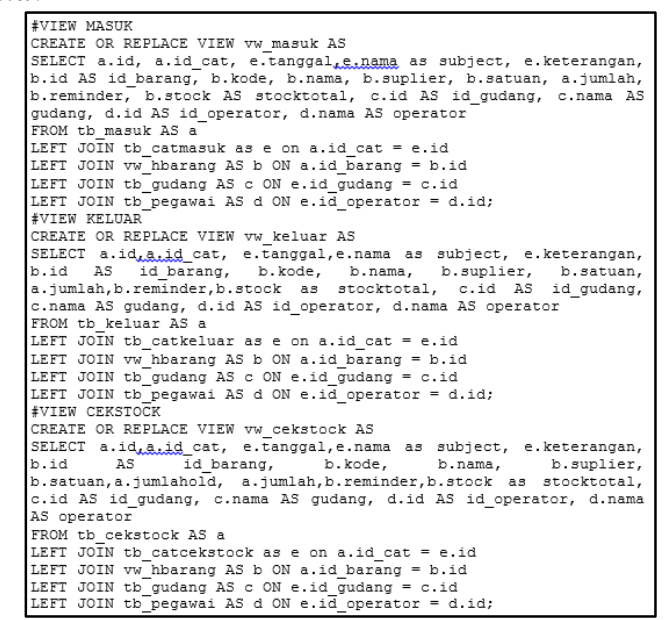

Gambar 45 Membuat view vw_masuk, vw_keluar, vw_cekstock

Pada Query yang terdapat pada Gambar 45 digunakan untuk membuat views yang menggabungkan data masuk, keluar, dan cekstock yang sudah ternormalisasi.

\begin{tabular}{|c|}
\hline 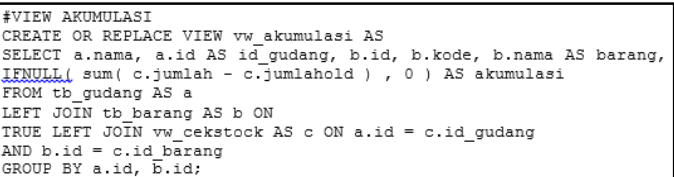 \\
\hline
\end{tabular}

Gambar 46 Membuat view vw_akumulasi

View vw_akumulasi dibuat dengan menggunakan kode seperti pada Gambar 46.

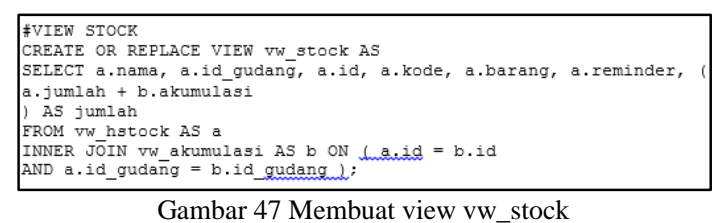

Pada Gambar 47 ditunjukkan kode yang digunakan untuk membuat view vw_stock.

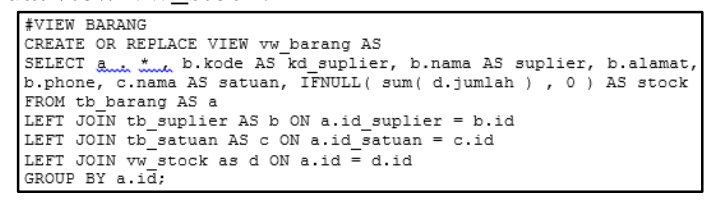

Gambar 48 Membuat view vw_barang

View vw_barang dibuat menggunakan kode seperti pada Gambar 48.

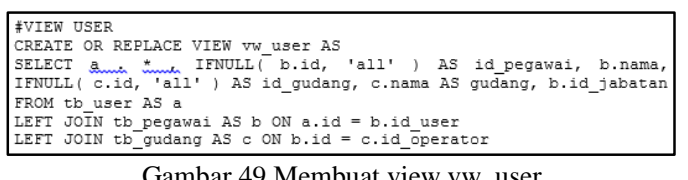

Gambar 49 Membuat view vw_user

View vw_user yang dibuat dengan menggunakan kode seperti pada Gambar 49.

Dari pembuatan views tersebut maka diharapkan aplikasi ini dapat mempermudah programmer dengan menyediakan informasi yang sudah diolah, sehingga pada sisi pemrogramman hanya cukup menampilkannya saja.

\section{- $\quad$ Pembuatan Resource Sharing}

Pembuatan Resource sharing ini bertujuan agar aplikasi yang dibuat dapat menggunakan sumberdaya yang ada pada Sistem Informasi sehingga basisdatanya akan terpusat atau terintegrasi. Langkah pertama dalam membuat Resource Sharing ini adalah mengijinkan Webserver diakses oleh aplikasi dengan cara mengaktifkan Cross Origin Resource Sharing(CORS).

- Pembuatan Aplikasi

Pada Gambar 60 merupakan tampilan dari Halaman Login, selain itu nantinya ketika tombol menu native android ditekan maka akan muncul menu yang berfungsi untuk menutup aplikasi.

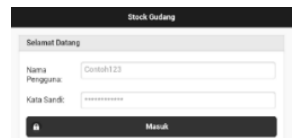

\section{Gambar 60 Tampilan setelah loadUrl.}

Pada menu Masuk menampilkan daftar Nota Masuk seperti pada Gambar 61, menu Keluar menampilkan daftar Nota Keluar seperti pada Gambar 62, sedangkan mеnи Persediaan menampilkan jumlah persediaan barang seperti yang ada pada Gambar 63.

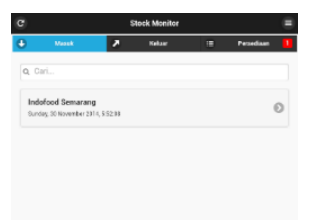

Gambar 61 Tampilan Daftar Barang. 


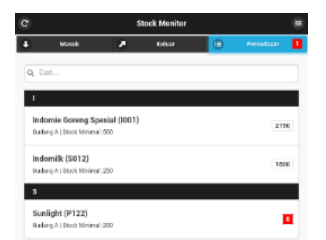

Gambar 63 Tampilan Data Persediaan Barang.

Proses pengambilan data ulang ditunjukkan pada Gambar 64. Tampilan Sidemenu seperti pada Gambar 65.
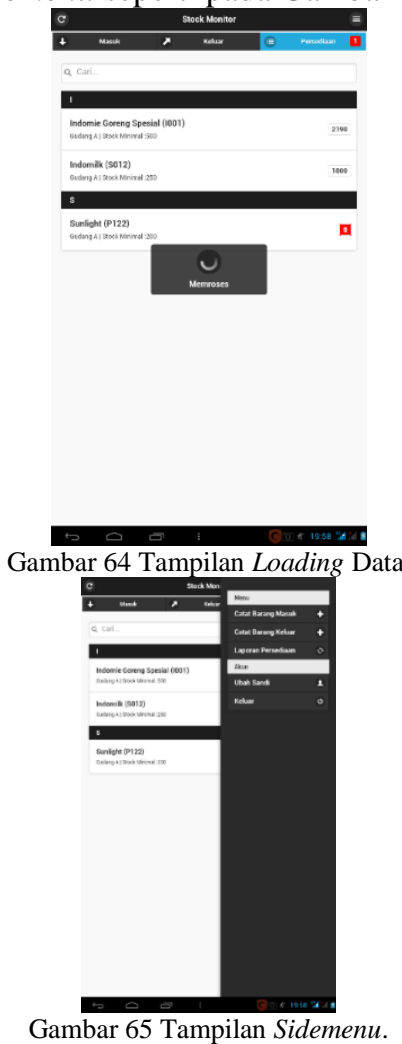

Tampilan dari halaman masukkan dapat dilihat pada Gambar 66 hingga Gambar 68. Gambar 66 merupakan Masukkan Barang, pada Gambar 67 dan 68 menunjukkan ketika pengguna mengisi kolom masukkan.

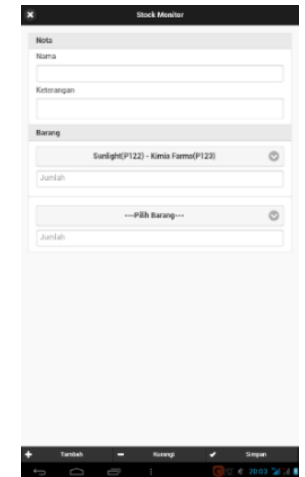

Gambar 66 Tampilan Masukkan Barang Masuk.
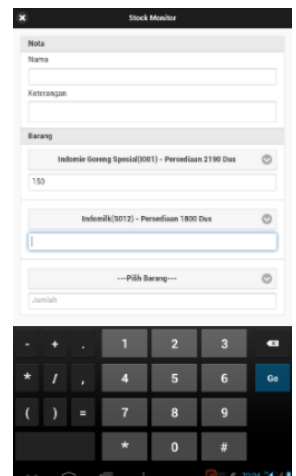

Gambar 67 Tampilan Masukkan Barang.

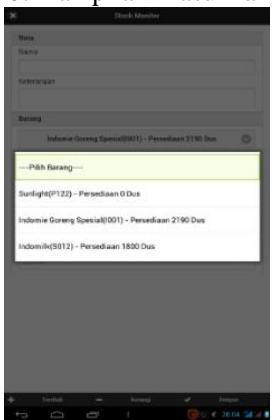

Gambar 68 Tampilan Pilihan Barang.

Pada Gambar 69 merupakan tampilan dari Pop-up yang masukkan datanya sudah benar, sedangkan pada Gambar 70 merupakan tampilan dari pesan error karena data yang dimasukkan belum sesuai.

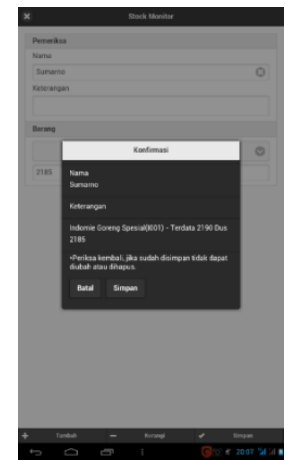

Gambar 69 Tampilan Pop-up konfirmasi simpan data.

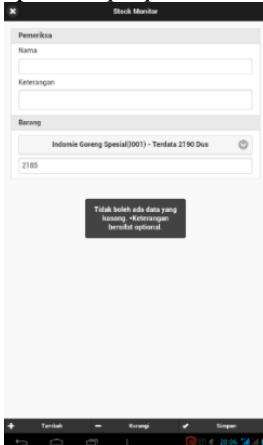

Gambar 70 Tampilan Pesan ketika Field Nama dikosongkan. Pada Gambar 71 ditunjukkan Tampilan Halaman Laporan Persediaan.

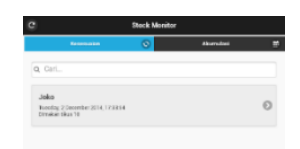


72.

Tampilan dari halaman "Rincian" dapat dilihat pada Gambar

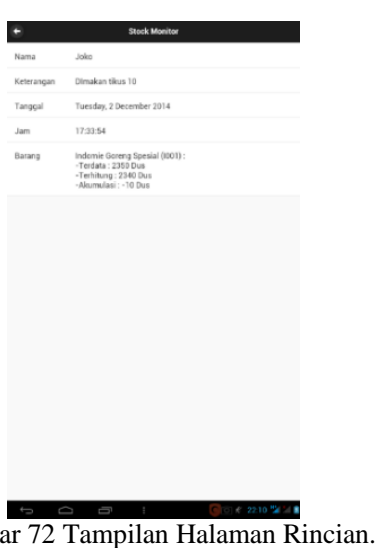

Pada Gambar 73 merupakan Tampilan Pop-up ketika Menu Ubah Kata Sandi ditekan.

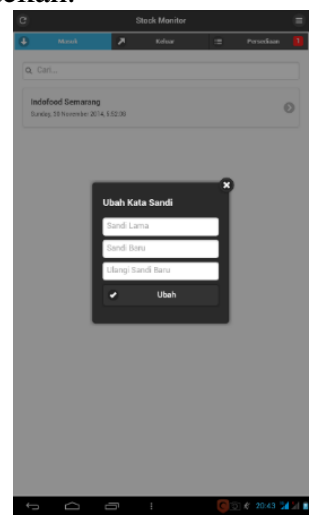

Gambar 73 Tampilan Pop-up Ubah Kata Sandi.

\section{B. Pengujian}

Pengujian pada pembuatan aplikasi ini akan menggunakan pengujian white box, dimana setiap fungsi yang ada akan diuji secara rinci jalur-jalur logika yang ada. Metode pengujiannya menggunakan Struktur Kontrol Program untuk memperoleh kasus uji. Pengujian akan dilakukan untuk masing-masing jalur, cabang dan perintah.

Fungsi login, terdapat beberapa fungsi yang digunakan pada saat pengguna melakukan login, yaitu fungsi pemeriksaan yang ada pada sisi Aplikasi, fungsi proses yang ada sisi webserver serta fungsi pemeriksaan hasil dari proses login yang telah dilakukan pada sisi Aplikasi, flowchart seperti pada Gambar 74 menunjukkan proses yg dilakukan.

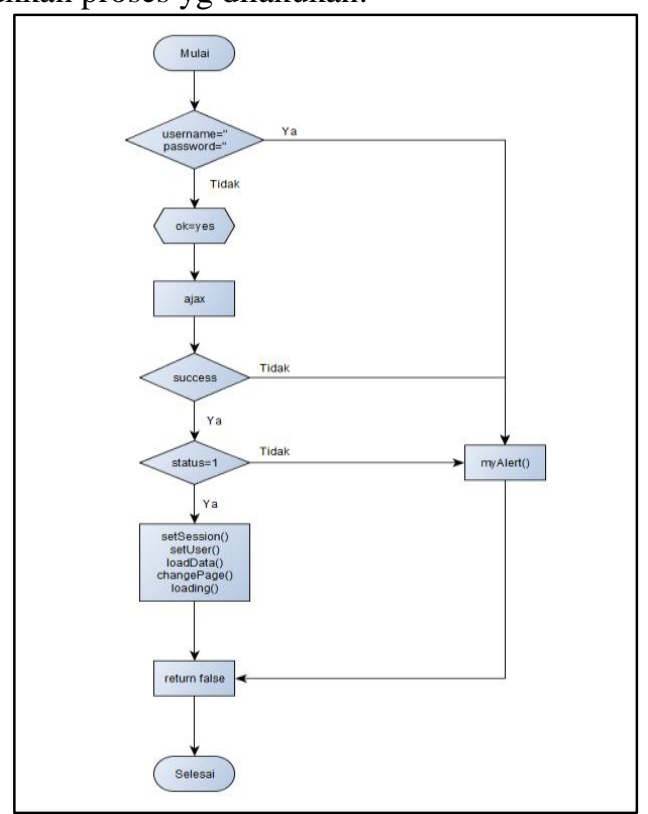

Gambar 74 Flowchart proses login sisi Pengguna

Jurnal Teknologi dan Sistem Komputer, Vol.3, No.2, April 2015 (e-ISSN: 2338-0403
Proses loadData() dapat dilihat pada flowchart gambar 75 .

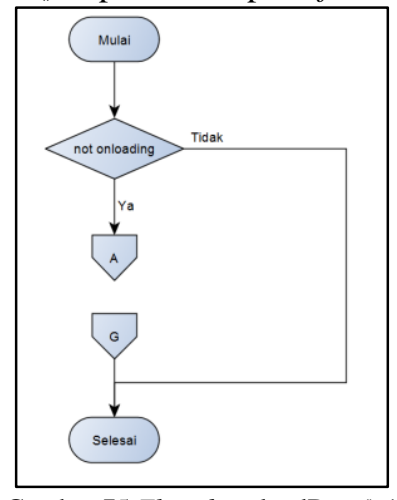

Gambar 75 Flowchart loadData() 1

Pada flowchart gambar 75 terlihat fungsi akan mengecek terlebih dahulu apakah aplikasi sedang melakukan loading atau tidak, setelah itu dilanjutkan ke proses pertama yang terlihat pada flowchart gambar 76.

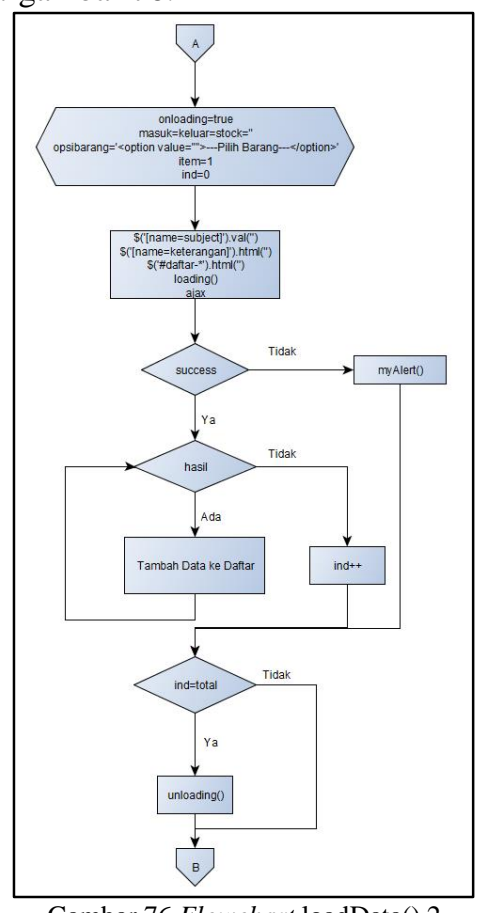

Gambar 76 Flowchart loadData() 2

Pada Gambar 77 terdapat tiga fungsi ajax, yaitu barang keluar, persediaan barang dan pilihan barang yang digunakan untuk menghasilkan pilihan barang yang dinamis mengikuti basisdata pada saat memasukkan data.

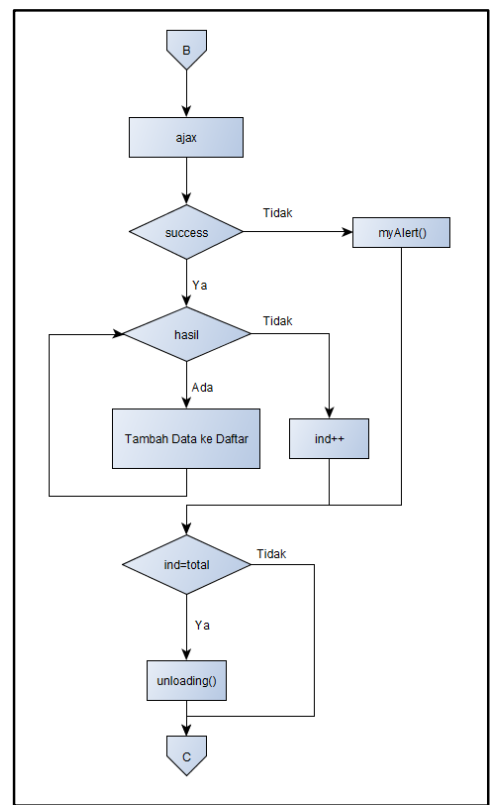

Gambar 77 Flowchart loadData() 3T Jiskom - 331 


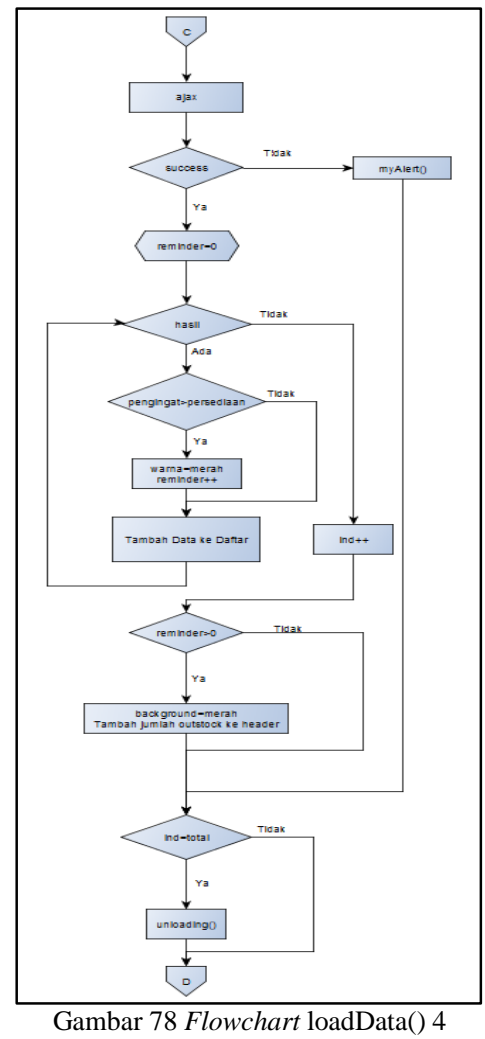

Pada flowchart berikutnya seperti pada Gambar 78 merupakan ajax yang digunakan untuk menambahkan ke daftar persediaan barang.

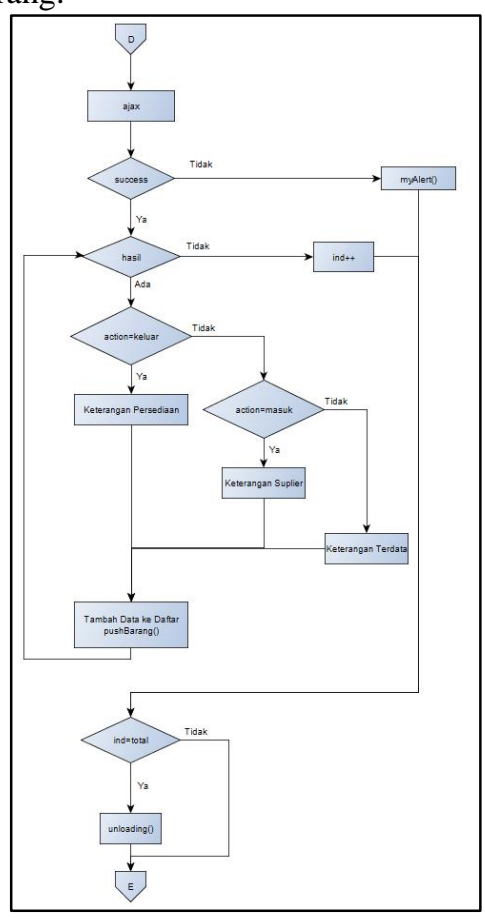

Gambar 79 Flowchart loadData() 5

Fungsi ajax selanjutnya digunakan untuk mengambil data untuk membuat pilihan barang ketika memasukkan data barang masuk, keluar, serta laporan persediaan. Pada flowchart gambar 79 proses pengiriman ajax akan dilakukan ketika prosesnya sukses maka akan dijalankan perulangan untuk menambahkan data ke dalam daftar.

Pada flowchart gambar 80 menunjukkan proses yang akan dilakukan oleh fungsi ajax laporan persediaan.

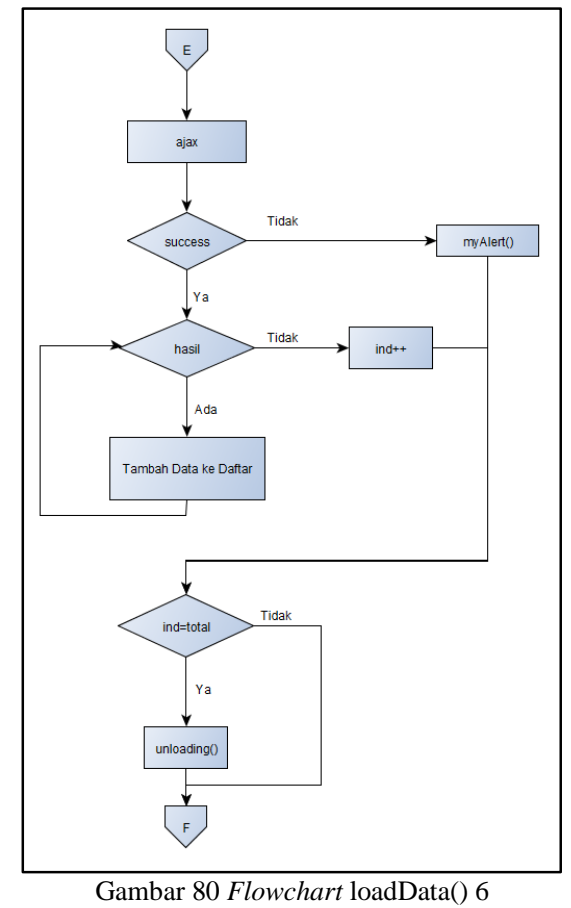

Pada gambar 81 menunjukkan proses yang akan dilakukan, proses yang terjadi mirip dengan proses yang ada pada fungsi ajax persediaan barang, perbedaannya adalah pada fungsi ajax ini header akumulasi persediaan tidak akan diubah.

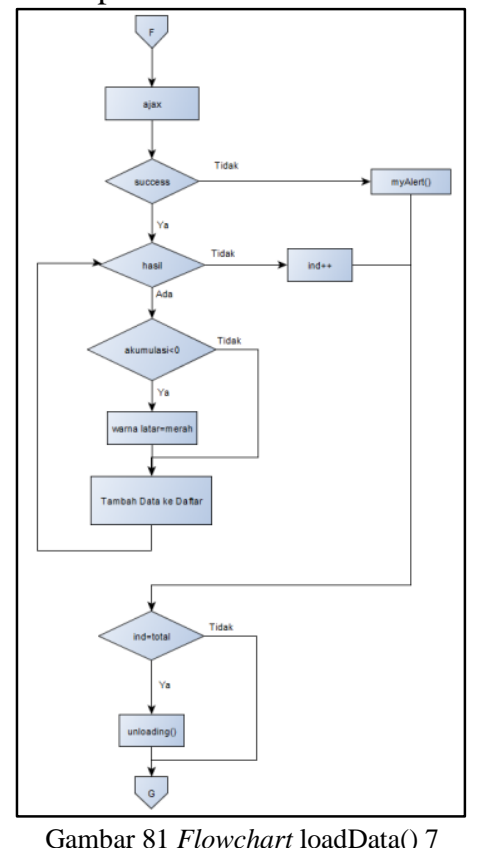

Pada Gambar 82 menunjukkan bagaimana proses fungsi createPop() berjalan.

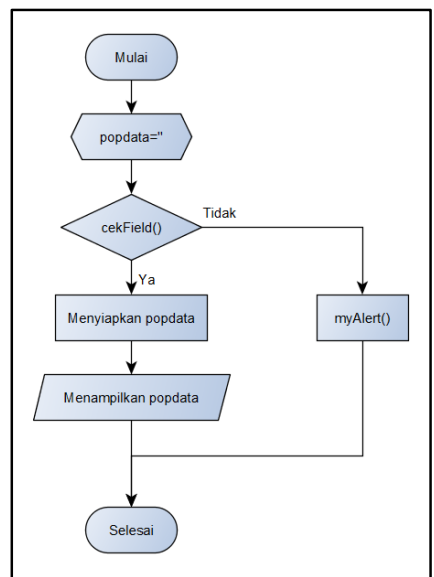

Gambar 82 Flowchart createPop()

JTsiskom - 332 
Pada gambar 83 menunjukkan proses yang akan dijalankan pada fungsi confirmation().

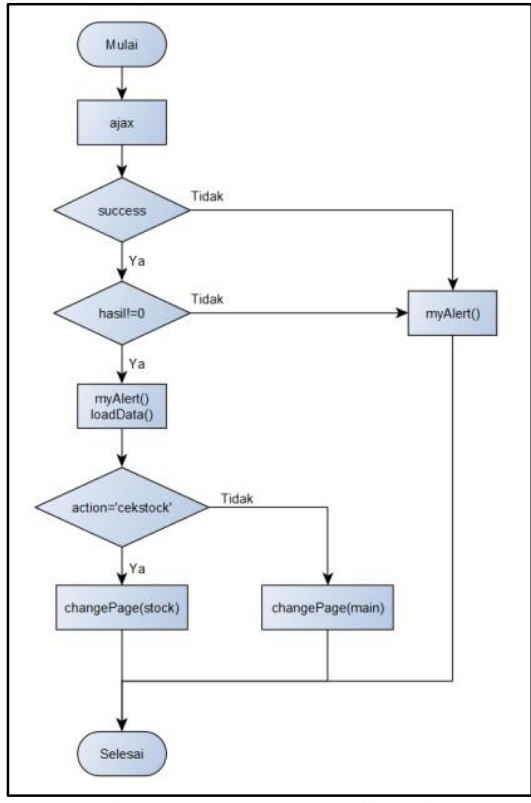

Gambar 83 Flowchart confirmation()

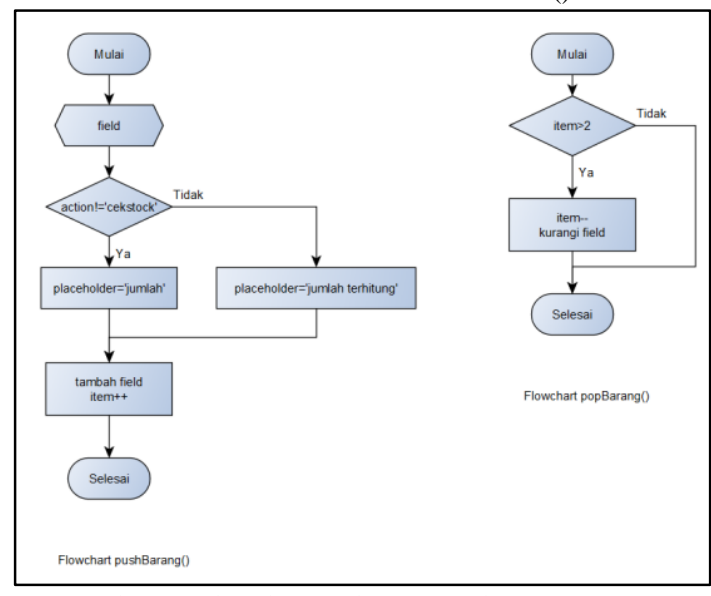

Gambar 84 Flowchart pushBarang() dan popBarang()

Pada gambar 84 kiri yang merupakan flowchart pushBarang(), sedangkan pada flowchart kanan gambar 84 menunjukkan proses yang terjadi ketika terjadi popBarang().

Fungsi terakhir adalah fungsi gantiPass(), ini dapat dilihat pada flowchart Gambar 85.

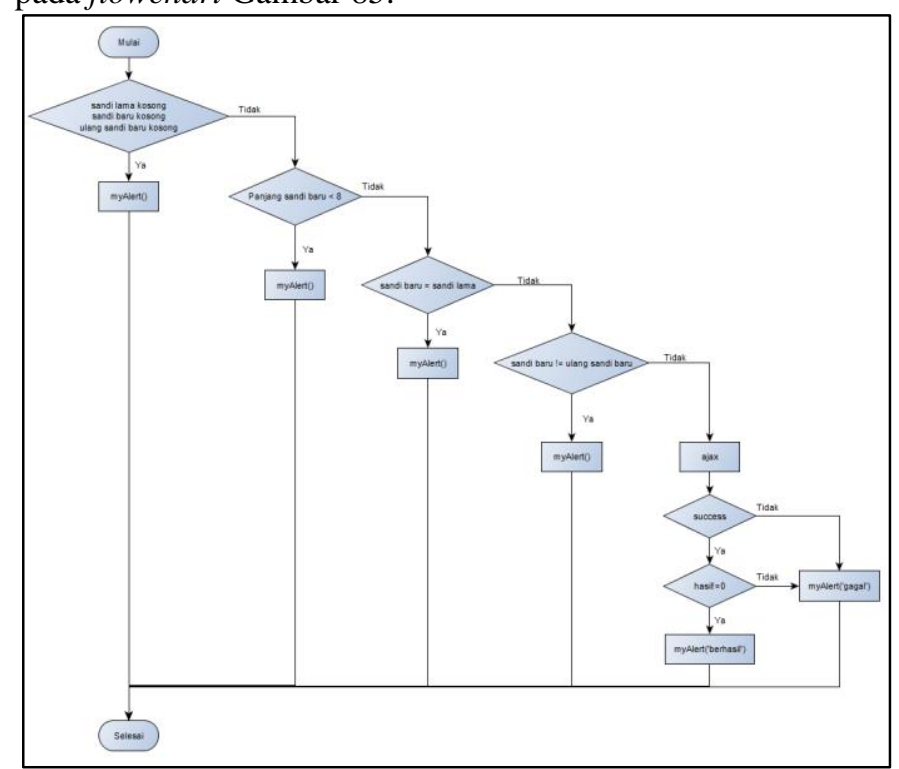

Gambar 85 Flowchart gantiPass()

\section{KESIMPULAN}

Dari hasil pengujian dan analisis pendataan barang di gudang berbasis Android dapat disimpulkan hal-hal sebagai berikut:

1. Pembuatan sistem terintegrasi pendataan barang di gudang dapat digunakan untuk membantu proses pendataan barang.

2. Pembuatan view pada basisdata memberikan kemudahan dalam melakukan perancangan suatu sistem, karena dengan view penyediaan informasi yang dibutuhkan oleh sistem diolah sekali tanpa perlu mengolahnya dalam aplikasi.

3. Pembuatan sistem terintegrasi yang dinamis sangat diperlukan sehingga ketika membuat suatu aplikasi terintegrasi, aplikasi tersebut dapat diimplementasikan diberbagai sistem yang berbeda tanpa harus melakukan pengubahan secara drastis terhadap sistem yang sudah ada.

4. Pembuatan aplikasi berbasis Mobile dengan menggunakan WebView memberikan kemudahan bagi pengembang dalam membuat suatu aplikasi berbasis mobile, karena dengan pemanfaatan WebView aplikasi yang dikembangkan dapat langsung diberikan karakteristik yang dimiliki setiap platform yang berbeda sehingga dalam mengembangkan aplikasi ini hanya cukup membuat satu aplikasi yang dapat dipindahkan langsung baik dari iOs ke Android, maupun sebaliknya dari Android ke iOs, atau bahkan Mobile Web Application yang ditempatkan pada Webserver.

5. Sistem terintegrasi pendataan barang di gudang bermanfaat dalam membantu proses pendataan barang, yang memberikan efisiensi waktu karena pengubahan data pada semua sistem secara realtime.

6. Sistem terintegrasi pendataan barang di gudang memberikan efektifitas kerja kepada Operator karena dengan data yang terintegrasi, informasi yang dibutuhkan oleh Operator dapat langsung dilihat.

\section{SARAN}

Saran yang diberikan dalam upaya pengembangan aplikasi yang lebih baik dikemudian hari.

1. Penambahan fitur barcode untuk masukkan data barang.

2. Penambahan fitur ubah data yang melibatkan Operator Sistem Informasi dan Operator di Gudang dengan tujuan memberikan keamanan data dari pengubahan data yang tidak bertanggung jawab.

3. Penambahan fitur obrolan dan pesan untuk memberikan kemudahan dalam melakukan komunikasi dari Gudang dan Pusat.

4. Pengubahan fungsi "Kurangi" pada saat memasukkan data, dengan memberikan fungsi hapus per field sehingga ketika data pada bagian awal ingin dihapus tidak perlu mengubahubah data lainnya.

5. Penambahan fitur multi masukkan sehingga pengguna dapat menambahkan data beberapa nota berbeda dalam satu waktu

\section{DAFTAR PUSTAKA}

Ariona, R., 2013. Belajar HTML dan CSS - Tutorial Fundamental dalam Mempelajari HTML dan CSS,

ARIZA, K., 2014. Pembuatan Aplikasi Informasi Tagihan Listrik Berbasis Android. Skripsi, Fakultas Ilmu Komputer, p.3. Available at: http://eprints.dinus.ac.id/13343/ [Accessed November 23, 2014].

Awalin, R.A.N., 2012. Analisis dan Perancangan Sistem Informasi Perpustakaan Berbasis Java di SD Negeri Jebeng. , pp.5-7. 
Cahyono, H., 2014. Mengenal Java sebagai Pemrograman Berorientasi Objek dam Implementasi Thread di Lingkungan UNIX/LINUX. , 1(1), pp.2-11.

Dwiartara, L., 2012. Menyelam dan Menaklukan Samudra PHP. Ilmuwebsite. com, p.3. Available at: http://scholar.google.com/scholar?hl=en\&btnG=Search\&q=inti tle:menyelam+dan+menaklukan+samudra+php\#0 [Accessed November 9, 2014].

Elisabeth, R. \& Eric, F., 2012. Head first HTML and CSS 2nd ed., Available at: http://dl.acm.org/citation.cfm?id=2458651 [Accessed November 9, 2014].

Haviluddin, 2011. Memahami Penggunaan UML ( Unified Modelling Language ). , 6(1), p.2.

jquery.com, jQuery. Available at: http://jquery.com/ [Accessed November 15, 2014].

Jquerymobile.com, jQuery Mobile. Available at: http://jquerymobile.com/ [Accessed November 15, 2014].

Kristanti, T., 2012. Integrasi Enterprise (Studi Kasus: Yayasan Pendidikan "X"). Jurnal Sistem Informasi, 4, p.19. Available at: http://majour.maranatha.edu/index.php/jurnal-sisteminformasi/article/viewFile/515/pdf [Accessed November 23, 2014].

McLaughlin, B., 2012. PHP \& MySQL: The Missing Manual, Available at: http://scholar.google.com/scholar?hl=en\&btnG=Search\&q=inti tle:No+Title\#0 [Accessed November 15, 2014].
Morrison, M., 2007. Head first javascript, Available at: http://books.google.com/books?hl=en \&lr=\&id=xsmBjw814qw C\&oi=fnd\&pg=PR9\&dq=Head+First + Javascript\&ots=bqGRal wTcB\&sig=VmwauvAc22uIrqGoHGD-IoMKS0Y [Accessed November 15, 2014].

Noertjahyana, A., 2002. Studi Analisis Rapid Application Development sebagai Perangkat Lunak. , 3(2), pp.74-79.

Sierra, K. \& Bates, B., 2005. Head First Java 2nd ed., Available at:

http://scholar.google.com/scholar?hl=en\&btnG=Search\&q=inti tle:No+Title\#0 [Accessed November 9, 2014].

Simon, J., 2011. Head First Android Development. , p.v,vi. Available

at: http://hydracortex1.torrenticity.com/torrent/9369097/Head_Fir st_Android_Development.pdf [Accessed November 9, 2014].

Solichin, A., 2010. MySQL 5: Dari Pemula Hingga Mahir. Jakarta: Achmatim. net, pp.6-8,28,29,35,36. Available at: http://books.google.com/books?hl=en \&lr=\&id=HCNGBAAA QBAJ\&oi=fnd\&pg=PA3\&dq=MySQL+-

+ Dari+Pemula + Hingga + Mahir\&ots $=$ FsFoUluhmW\&sig=LCzn HlnEiO_OzO1ui51BPdCCyic [Accessed November 15, 2014].

Solichin, A., 2005. Pemrograman Web dengan PHP dan MySQL. Universitas Budi Luhur., Jakarta, p.14,15. Available at: http://110.138.248.171/materi/Pemrograman Web dengan PHP MySQL.pdf [Accessed November 21, 2014].

Suehring, S., JavaScript Step by Step , Second Edition 2nd ed., 